\title{
New and revised maimetshid wasps from Cretaceous ambers (Hymenoptera, Maimetshidae)
}

\author{
Vincent Perrichot ${ }^{1,2, \dagger}$, Jaime Ortega-Blanco ${ }^{3, \ddagger}$, Ryan C. McKellar ${ }^{4, \S}$, Xavier

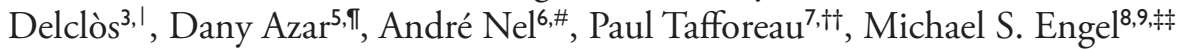

I CNRS UMR 6118 Géosciences and Observatoire des Sciences de l'Univers de Rennes, Université Rennes 1, Campus de Beaulieu bât. 15, 263 avenue du Général Leclerc, 35042 Rennes Cedex, France 2 Biodiversity Institute, University of Kansas, Lawrence, Kansas 66045, USA 3 Departament d'Estratigrafia, Paleontologia i Geociències Marines, Facultat de Geologia, Universitat de Barcelona, Martí i Franqués s/n, 08028 Barcelona, Spain 4 Department of Earth and Atmospheric Sciences, 1-26 Earth Sciences Building, University of Alberta, Edmonton, Alberta T6G 2E3, Canada 5 Lebanese University, Faculty of Sciences II, Department of Biology, Fanar Matn P.O. Box 26110217, Lebanon 6 CNRS UMR 7205, Muséum National d'Histoire Naturelle, CP 50, Entomologie, 45 rue Buffon, F-75005, Paris, France 7 European Synchrotron Radiation Facility, BP 220, 6 rue Jules Horowitz, 38043 Grenoble, France 8 Division of Entomology (Paleoentomology), Natural History Museum, and Department of Ecology and Evolutionary Biology, 1501 Crestline Drive - Suite 140, University of Kansas, Lawrence, Kansas 66049-2811, USA 9 Division of Invertebrate Zoology, American Museum of Natural History, Central Park West at 79th Street, New York, New York 10024-5192, USA

† urn:lsid:zoobank.org:author:BC661D50-24D5-4C74-B0C3-FB56E47ED306

¥ urn:lsid:zoobank.org:author:F1233787-B8DF-4A2F-921F-47085A576641

§ urn:lsid:zoobank.org:author:C22E0D57-2231-4EAF-91C7-949B67A78E9A

| urn:lsid:zoobank.org:author:8CCF4229-88BF-49B5-9A9A-9FB3F6BBEF55

I urn:lsid:zoobank.org:author:2F731869-E5AA-49A5-8806-3ACF2211134B

\# urn:lsid:zoobank.org:author:98DF555A-16A0-4073-871C-E38BB506C676

†† urn:lsid:zoobank.org:author:02669393-1A14-46F8-A8D8-5B43AAF08EFO

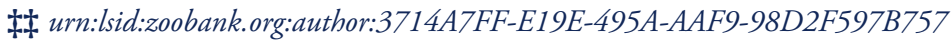

Corresponding authors: Vincent Perrichot (vincent.perrichot@univ-rennes1.fr), Jaime Ortega-Blanco (j.ortegablanco@ ub.edu), Ryan C. McKellar (rcm1@ualberta.ca)

Academic editor: D. Shcherbakov | Received 29 April 2011 | Accepted 23 June 2011 | Published 24 September 2011

urn:lsid:zoobank.org:pub:F6CD5453-CD02-445C-A721-D166AC257093

Citation: Perrichot V, Ortega-Blanco J, McKellar RC, Delclòs X, Azar D, Nel A, Tafforeau P, Engel MS (2011) New and revised maimetshid wasps from Cretaceous ambers (Hymenoptera, Maimetshidae). In: Shcherbakov DE, Engel MS, Sharkey MJ (Eds) Advances in the Systematics of Fossil and Modern Insects: Honouring Alexandr Rasnitsyn. ZooKeys 130: 421-453. doi: 10.3897/zookeys.130.1453

Copyright Vincent Perrichot et al. This is an open access article distributed under the terms of the Creative Commons Attribution License, which permits unrestricted use, distribution, and reproduction in any medium, provided the original author and source are credited. 


\begin{abstract}
New material of the wasp family Maimetshidae (Apocrita) is presented from four Cretaceous amber deposits - the Neocomian of Lebanon, the Early Albian of Spain, the latest Albian/earliest Cenomanian of France, and the Campanian of Canada. The new record from Canadian Cretaceous amber extends the temporal and paleogeographical range of the family. New material from France is assignable to Guyotemaimetsha enigmatica Perrichot et al. including the first females for the species, while a series of males and females from Spain are described and figured as Iberomaimetsha Ortega-Blanco, Perrichot \& Engel, gen. n., with the two new species Iberomaimetsha rasnitsyni Ortega-Blanco, Perrichot \& Engel, sp. n. and I. nihtmara Ortega-Blanco, Delclòs \& Engel, sp. n.; a single female from Lebanon is described and figured as Ahiromaimetsha najlae Perrichot, Azar, Nel \& Engel, gen. et sp. n., and a single male from Canada is described and figured as Ahstemiam cellula McKellar \& Engel, gen. et sp. n. The taxa are compared with other maimetshids, a key to genera and species is given, and brief comments made on the family.
\end{abstract}

\title{
Keywords
}

Hymenoptera, Maimetshidae, France, Lebanon, Spain, Canada, Neocomian, Albian, Campanian, Mesozoic, taxonomy

\section{Dedication}

We lovingly dedicate this humble contribution to the discoverer of the Maimetshidae, our friend and colleague, Prof. Alexandr P. Rasnitsyn, on the occasion of his $75^{\text {th }}$ birthday. It is greatly hoped that Alex, as the great docent of hymenopterological paleontology, will look upon our work with favor and pride, knowing that his rich body of inquiry has inspired every aspect of our own probes into the history of this fascinating order.

\section{Introduction}

The family Maimetshidae was established as an extinct lineage of apocritan wasps based on a single incomplete female and male preserved in Santonian Taimyr amber (Rasnitsyn 1975). A single genus and species, Maimetsha arctica Rasnitsyn, was recognized and considered to be intermediate between Megalyridae and Ceraphronoidea, linking these otherwise disparate groups (Rasnitsyn 1975, 2002).

More than a quarter century later, Perrichot et al. (2004a) described a second genus and species which shared considerable similarities with Maimetsha Rasnitsyn and Cretogonalys Rasnitsyn, a genus originally attributed to Trigonalyidae but subsequently recognized as a possible maimetshid (Rasnitsyn and Brothers 2009). Given the uncertainties of the time, Guyotemaimetsha Perrichot et al. was considered as family incertae sedis (Perrichot et al. 2004a). Later, Perrichot (2009) reported new specimens of Guyotemaimetsha as well as undescribed material from Spanish amber, all of which appeared to suggest closer affinities with Trigonalyidae [This name often appears as Trigonalidae, given that Cresson (1887) first used this spelling. However, ICZN (1999: Art. 29.3) 
dictates that the name is to be based on the correct stem by deleting the case ending of the genitive singular, in the present case giving "Trigonalyd-", thus the name would be automatically corrected to Trigonalydidae, with the same author and date, except that (Art. 29.3.1.1) notes that the unelided form, Trigonalyidae, is to be retained since the elided form (Trigonalydidae) is not in prevailing usage. Accordingly, Trigonalidae is a nomen imperfectum, which is recte Trigonalyidae Cresson, 1887].

Maimetshidae are presently known only from the Cretaceous and largely as inclusions in amber, similar in this respect to the families Radiophronidae (OrtegaBlanco et al. 2010), Stigmaphronidae (Rasnitsyn 1975, 1991; Engel and Grimaldi 2009; Ortega-Blanco et al. in press; McKellar and Engel in press), Alavarommatidae (Ortega-Blanco et al. 2011a), Gallorommatidae (Gibson et al. 2007; Ortega-Blanco et al. 2011a), and Serphitidae (Kozlov and Rasnitsyn 1979; McKellar and Engel 2011; Ortega-Blanco et al. 2011b; Engel et al. 2011). Rasnitsyn and Brothers (2009) described various maimetshids from Late Cretaceous compressions, and, as mentioned before, Cretogonalys is possibly also of this family, as could be the species of Turgonalus Rasnitsyn (Rasnitsyn 1990; Rasnitsyn et al. 1998).

The classification of Maimetshidae has been controversial, with various alternative interpretations of their putative relationships. For example, many authors have recognized them as an extinct, isolated family of Ceraphronoidea s.l. (Rasnitsyn 1975, 1977, 1988; Ronquist et al. 1999; Rasnitsyn and Brothers 2009; Perrichot 2009; Ortega-Blanco et al. 2010), while Shaw $(1988,1990)$ considered them as a basal clade within the Megalyridae. Vilhelmsen et al. (2010a) provided the first critical phylogenetic evaluation for the group, recognizing Maimetshidae as sister to Trigonalyidae, uniting these two by at least asymmetrical mandibles (not observed in all maimetshids) and the tarsal plantulae in females. Maimetshidae differ from Trigonalyidae, however, at least by the ovipositor exserted (instead of concealed in Trigonalyidae: vide Oeser 1962) and the absence of antennal tyloids (these are present in all trigonalyids except the primitive genus Orthogonalys Schulz: vide Carmean and Kimsey 1998). While the relationship between Maimetshidae and Trigonalyidae now seems well corroborated, the classification of these within an expanded Ceraphronoidea (or Stephanoidea sensu Rasnitsyn and Brothers 2009 = Stephanidae, Megalyridae, Trigonalyidae, Maimetshidae, Ceraphronidae, Megaspilidae, Stigmaphronidae, and Radiophronidae) is not well supported, and the phylogenetic placement of Ceraphronoidea s.str. (= Ceraphronidae, Megaspilidae, Stigmaphronidae, and Radiophronidae) is debatable, although many higher-level analyses do recover them as part of the Evaniomorpha (Sharkey 2007; Davis et al. 2010; Vilhelmsen et al. 2010b; Rasnitsyn and Zhang 2010) rather than Proctotrupomorpha (Ronquist et al. 1999; Sharkey and Roy 2002). Most recently Heraty et al. (2011) failed to recover a monophyletic Evaniomorpha, although ceraphronoids did not group with Proctotrupomorpha, but their analysis also had Orussidae nested within a paraphyletic evaniomorph grade which is certainly controversial.

Herein we provide a systematic overview of new material of maimetshids in Cretaceous amber, including the descriptions of three new genera and four new species. 


\section{Material and methods}

The species discussed herein were recovered from four different Cretaceous deposits, two in southwestern Europe (France and Spain), one in western Asia (Lebanon), and the last from northcentral North America (Canada). Details of each are briefly summarized below and more thorough discussions on their stratigraphy, paleoecology, and paleoenvironment can be found in Perrichot et al. (2010), Peñalver and Delclòs (2010), Azar et al. (2010), and McKellar and Wolfe (2010), respectively. Morphological terminology generally follows that used elsewhere in the Hymenoptera (e.g., Goulet and Huber 1993), and for consistency the wing terminology as applied in Perrichot et al. (2004a). Acronyms for the institutions with collections studied herein are as follows: MNHN, Muséum National d'Histoire Naturelle, Paris, France; IGR, Géosciences Rennes, Université Rennes 1, Rennes, France; MCNA, Museo de Ciencias Naturales de Álava, Vitoria-Gasteiz, Spain; and CNC-CAS, Canadian National Collection of Insects and Arthropods, Ottawa, Canada.

Photomicrographic images of specimens preserved in transparent amber were prepared using digital cameras attached to stereomicroscopes or to an Infinity K-2 long-distance microscopic lens. Fossils preserved in opaque amber were first detected using propagation phase contrast X-ray synchrotron microradiography, then three-dimensionally imaged using microtomography (PPC-SR $\mu \mathrm{CT}$ ), a non-invasive method which allows incomparable possibilities for the visualization of both external and internal structures of amber fossils (Soriano et al. 2010; Perreau and Tafforeau 2011). Imaging was performed on beamline ID 19 of the European Synchrotron Radiation Facility (ESRF) in Grenoble using local tomography protocol (Tafforeau et al. 2006; Lak et al. 2008). The microtomographic scan of specimen IGR.ARC-370.7 was performed using a monochromatic beam at $30 \mathrm{keV}$ with an isotropic voxel size of $5.06 \mu \mathrm{m}$ and $990 \mathrm{~mm}$ of propagation distance. The tomography was obtained using a 180 degree continuous scan with 1500 projections and $0.5 \mathrm{~s}$ of exposure time. The scan of specimen IGR.ARC-378.2 was performed at $25 \mathrm{keV}$ with an isotropic voxel size of $1.67 \mu \mathrm{m}, 50 \mathrm{~mm}$ of propagation distance, and $0.12 \mathrm{~s}$ of exposure time. After the scan, data were reconstructed using a filtered back-projection algorithm adapted for local tomography applications (PyHST software, ESRF) and adapted ring artifacts correction protocols. Specimen IGR.ARC-370.7 was segmented in 3D using region growing techniques with VGStudioMax (Volume Graphics, Heidelberg, Germany). All of the synchrotron microtomographic data (original stacks of slices, segmentations, animations, pictures, and 3D-volume models) are available at the paleontological online database of the ESRF (http://paleo.esrf.eu), and 3D models in ABS plastic are deposited with the amber piece in Rennes University and at the ESRF.

French amber. Since the description of G. enigmatica by Perrichot et al. (2004a) based on two males, eight new conspecific specimens have been found, including two females previously unknown, five males, and one specimen of uncertain gender. Three 
further individuals assignable to Maimetshidae may also belong to this species but are too incompletely preserved for accurate attribution.

Six out of the eight new specimens were found in amber from the same outcrop as the type series, i.e., the Font-de-Benon Quarry near the village of Archingeay, in Charente-Maritime, southwestern France. The amber pieces were collected within the lowermost of two amber-bearing strata, e.g., the level A1sl-A sensu Batten et al. (2010) = A1sl1 sensu Néraudeau et al. (2002). The dating of this level remains problematic, it contains some palynomorphs (dinoflagellate cysts) suggesting a latest Albian age (Dejax and Masure 2005), while recently discovered megaspores are more indicative of the Early Cenomanian (Batten et al. 2010). Two other specimens were collected in a single piece of amber from the same stratigraphic level in the Cadeuil Quarry, about $30 \mathrm{~km}$ from Archingeay (see "Arc 1" and "Cdl 1" in Perrichot et al. 2010: figs 1-2).

Similar to the type series, four amber pieces were reworked using a scalpel as a microsaw and the five fossils, separated this way from their syninclusions, were embedded in Canada Balsam between cover slips following the method detailed in Perrichot et al. (2004b). The specimens were assigned collection numbers IGR.ARC-1, IGR.ARC-309.11, IGR.ARC378.1, IGR.CDL-2.5, and IGR.CDL.2.33. The three other fossils (collection numbers IGR.ARC-370.7, IGR.ARC.378.2, and IGR.ARC-393.4) are preserved in pieces of fully opaque amber and were imaged using PPC-SR $\mu \mathrm{CT}$ as detailed above.

Spanish amber. The material originates from Peńacerrada I, in Moraza, Burgos Province, Basque-Cantabrian Basin, Spain (Peñalver and Delclòs 2010). Each fossil is preserved in a thin polished piece of amber, which has been embedded in a clear, synthetic block of epoxy resin according to the method of Corral et al. (1999) except for MCNA-9373, which is not embedded in epoxy. Specimen MCNA-9928, type specimen for one of the new species described herein, is well-preserved and almost complete. Specimen MCNA-13049, holotype for the second species from Spanish amber, is missing the apical parts of the metasoma, of the right antenna, and most legs. Other specimens are incomplete and fossilized in rather opaque amber, partly covered by small bubbles or foggy material, so that some parts are hidden or poorly visible.

Lebanese amber. The material originates from an outcrop near Maknouniyyeh Village, Caza (Department) of Jezzine, in southern Lebanon, which corresponds to an ancient field that was used for lignite mining during the French governance of Lebanon and World Wars I and II. The amber is found with lignite in grey lenses of clay corresponding to channels intercalated between fluvial sand deposition of Neocomian age. The precise dating of this sandstone remains problematic and could be anywhere between the Hauterivian and Early Aptian (Azar et al. 2010). The amber is dark orange to red, brittle, with a lot of carbonized vegetal inclusions. This may indicate that the resin was produced in response to a forest fire. The specimen considered herein is exquisitely preserved, missing only the apical portions of the mid and hind legs. It was fossilized in a piece of amber together with a beetle, an evaniid wasp, a roach, and a rhagionid fly, but each inclusion was separated from the others and embedded in 
Canada balsam between glass coverslips. The specimen is provisionally deposited in the Department of Entomology of the MNHN.

Canadian amber. The material was collected from the Taber Coal Zone within the uppermost Foremost Formation, at the Grassy Lake locality in southern Alberta, Canada (McKellar and Wolfe 2010). The specimen was prepared in a similar fashion to the Spanish material described above. The male holotype is nearly complete but is surrounded by a relatively thick layer of dark orange amber with multiple internal fractures; this renders observation difficult. Photographs were taken using glycerin and a cover slip. The type specimen exhibits minor taphonomic distortion, and is missing both metatarsi and much of the forewing apices.

\section{Systematic paleontology}

\section{Order Hymenoptera Linnaeus, 1758}

\section{Family Maimetshidae Rasnitsyn, 1975}

http://species-id.net/wiki/Maimetshidae

Maimetshidae Rasnitsyn, 1975: 73. Type genus: Maimetsha Rasnitsyn, 1975. Rasnitsyn 1988: 124; Ronquist et al. 1999: 33; Rasnitsyn and Brothers 2009: 192; Perrichot 2009: 2; Ortega-Blanco et al. 2010: 266; Vilhelmsen et al. 2010a: 674.

Dinapsinae [Megalyridae], partim: Shaw 1988: 107.

Dinapsini [Megalyridae], partim: Shaw 1990: 578.

Diagnosis. Modified from Rasnitsyn and Brothers (2009): Head hypognathous, without ocular carina, without subantennal groove accommodating antennal base; vertex with or without longitudinal median sulcus; antenna filiform, with scape short to moderate, never elongate, flagellomeres variable in number (14-19), most often 16, without apparent sexual dimorphism; mandibles often asymmetrical, with 3-4 teeth. Pronotum short medially; mesoscutum with notauli and median sulcus; axillae meeting anterior to mesoscutellum or separated by scutoscutellar sulcus; propodeum areolate. Forewing with costal space moderate to wide; $\mathrm{C}$ and pterostigma present; basal sections of Rs and M subequal in length, not continuously aligned (i.e., not forming smooth basal vein); cell [2 $\left.\mathrm{R}_{1}\right]$ (i.e., marginal cell) closed, wide (not triangular), moderately short to moderately long; cells [1Rs] and/or [2Rs] closed; cell [1M] closed, small, distant from [1Rs]; cell [2M] open or delimited by spectral or nebulous $2 \mathrm{~m}-\mathrm{cu}$; $1 \mathrm{cu}-\mathrm{a}$ antefurcal. Hind wing with no posterobasal lobe; 4-5 distal hamuli; basal cell [R] closed; free apex of Rs present, short to long; free apices of $\mathrm{M}$ and $\mathrm{Cu}$ short or absent, that of A absent. Legs with trochantelli; tibial spur formula 1-2-2; tarsi pentamerous; tarsal plantulae present in some females; pretarsal claws with preapical tooth. Metasoma rather short, compact, not much sculptured, attached low on propodeum, first segment longest [articulatory ring referred to by Rasnitsyn and Brothers (2009) is not 
evident and apparently an incorrect interpretation], apical sternum of female elongate, nearly reaching metasomal apex; ovipositor external but not very long, sheaths at most as long as metasoma, not fitting tightly to ovipositor (often preserved detached).

Included genera. Andyrossia Rasnitsyn and Jarzembowski, 2000 (Wealden, England, Barremian; a replacement name for Arossia Rasnitsyn and Jarzembowski in Rasnitsyn et al. 1998); Ahiromaimetsha Perrichot, Azar, Nel, and Engel gen n. (Lebanese amber, Neocomian); Iberomaimetsha Ortega-Blanco, Perrichot, and Engel gen. n. (Spanish amber, Lower Albian); Guyotemaimetsha Perrichot et al., 2004a (French amber, latest Albian/earliest Cenomanian); Afrapia Rasnitsyn and Brothers, 2009 (Orapa Mine, Botswana, Turonian); Afromaimetsha Rasnitsyn and Brothers, 2009 (Orapa Mine, Botswana, Turonian); Maimetshorapia Rasnitsyn and Brothers, 2009 (Orapa Mine, Botswana, Turonian); Maimetsha Rasnitsyn, 1975 (Taimyr amber, Santonian); and Ahstemiam McKellar and Engel gen. n. (Canadian amber, Campanian). Table 1 summarizes the species diversity of the family.

\section{Genus Guyotemaimetsha Perrichot, Nel \& Néraudeau, 2004a}

http://species-id.net/wiki/Guyotemaimetsha

Guyotemaimetsha Perrichot, Nel \& Néraudeau, 2004a: 159 [Incertae sedis in Ceraphronoidea sensu Rasnitsyn 2002]. Type species: Guyotemaimetsha enigmatica Perrichot, Nel \& Néraudeau, 2004a. Rasnitsyn and Brothers 2009: 192 [in Maimetshidae]; Ortega-Blanco et al. 2010: 266; Vilhelmsen et al. 2010a: 661.

Revised diagnosis. Male: total body length (excluding mandibles and parameres) 1.7 to $2.9 \mathrm{~mm}$; compound eyes oval and bulging, large, $0.66 \times$ height of head; vertex without longitudinal medial line; fine occipital carina present; mandibles asymmetrical, right with four teeth and left with three teeth; scape flattened laterally, short, its maximal width $0.9 \times$ its length; pedicel nearly as broad as long, $0.75 \times$ length of scape; 14 flagellar articles cylindrical in shape and progressively shortening and slightly narrowing; maxillary palpus apparently with five palpomeres; labial palpus apparently with three palpomeres, all short; forewing with pterostigma moderately long, shorter than [2R1]; r-rs originating within apical one-third of pterostigmal length; $2 \mathrm{R}$ present as long stub, about half length of 1R; [1M] small, nearly rhombic, with first abscissa of $\mathrm{R} s+\mathrm{M}$ one-half length of second abscissa $(2 \mathrm{Rs}+\mathrm{M})$, so that apical corner (junction of $\mathrm{Rs}+\mathrm{M}$ and $1 \mathrm{~m}-\mathrm{cu}$ crossvein) positioned anterior to pterostigma; [1Rs] triangular, with Rs and 1rs-m crossvein both fade to become nebulous posteriorly; cross-veins 2rs-m and $2 \mathrm{~m}$-cu at most spectral, generally absent; hind wing with cells $[\mathrm{R}]$ and $[\mathrm{Cu}]$ enclosed by nebulous veins, with free apex of $\mathrm{Cu}$.

Female: very similar to male but larger, total body length (excluding mandibles and ovipositor) 3.7 to $4.1 \mathrm{~mm}$; pedicel more elongate, $0.75 \times$ as broad as long, $0.85 \times$ length of scape; legs with tarsal plantulae; ovipositor apparently simple, not serrate or toothed. 
Table I. Known records for Maimetshidae s.l. (A = amber inclusion; $\mathrm{C}=$ compression fossil).

\begin{tabular}{|c|c|c|c|}
\hline Taxon & Stage & Geography & Sex \\
\hline \multicolumn{4}{|l|}{ Family Maimetshidae Rasnitsyn, 1975} \\
\hline \multicolumn{4}{|l|}{ Genus Andyrossia Rasnitsyn \& Jarzembowski, 2000} \\
\hline A. joyceae (Rasnitsyn \& Jarzembowski, 1998) & Barremian $(\mathrm{C})$ & England & ? \\
\hline \multicolumn{4}{|c|}{ Genus Ahiromaimetsha Perrichot, Azar, Nel \& Engel, gen. n. } \\
\hline A. najlae Perrichot, Azar, Nel \& Engel, sp. n. & Neocomian $(\mathrm{A})$ & Lebanon & q \\
\hline \multicolumn{4}{|c|}{ Genus Iberomaimetsha Ortega-Blanco, Perrichot \& Engel, gen. n. } \\
\hline I. nihtmara Ortega-Blanco, Delclòs \& Engel, sp. n. & Albian (A) & Spain & + $+0^{\top}$ \\
\hline I. rasnitsyni Ortega-Blanco, Perrichot \& Engel, sp. n. & Albian (A) & Spain & + $\hat{0}^{\lambda}$ \\
\hline \multicolumn{4}{|c|}{ Genus Guyotemaimetsha Perrichot et al., 2004} \\
\hline G. enigmatica Perrichot et al., 2004 & Albian/Cenomanian (A) & France & + $0^{\lambda}$ \\
\hline \multicolumn{4}{|l|}{ Genus Afrapia Rasnitsyn \& Brothers, 2009} \\
\hline A. globularis Rasnitsyn \& Brothers, 2009 & Turonian $(\mathrm{C})$ & Botswana & q \\
\hline A. variicornis Rasnitsyn \& Brothers, 2009 & Turonian $(\mathrm{C})$ & Botswana & 웅 \\
\hline \multicolumn{4}{|l|}{ Genus Afromaimetsha Rasnitsyn \& Brothers, 2009} \\
\hline A. robusta Rasnitsyn \& Brothers, 2009 & Turonian $(\mathrm{C})$ & Botswana & 우 \\
\hline \multicolumn{4}{|l|}{ Genus Maimetshorapia Rasnitsyn \& Brothers, 2009} \\
\hline M. africana Rasnitsyn \& Brothers, 2009 & Turonian $(\mathrm{C})$ & Botswana & 우 \\
\hline $\begin{array}{l}\text { Genus Ahstemiam McKellar \& Engel, gen. n. } \\
\text { A. cellula McKellar \& Engel, sp. n. }\end{array}$ & Campanian (A) & Canada & $0^{\pi}$ \\
\hline \multicolumn{4}{|l|}{ Genus Maimetsha Rasnitsyn, 1975} \\
\hline M. arctica Rasnitsyn, 1975 & Santonian (A) & Siberia & $q^{*}$ \\
\hline \multicolumn{4}{|c|}{ Incertae sedis (but possibly maimetshids, sensu Rasnitsyn \& Brothers 2009) } \\
\hline \multicolumn{4}{|c|}{ Genus Cretogonalys Rasnitsyn, $1977^{* *}$} \\
\hline C. taimyricus Rasnitsyn, 1977 & Cenomanian $(\mathrm{C})$ & Siberia & $?$ \\
\hline \multicolumn{4}{|l|}{ Genus Turgonalus Rasnitsyn, 1990} \\
\hline T. cooperi Rasnitsyn \& Jarzembowski, 1998 & Barremian $(\mathrm{C})$ & England & ? \\
\hline T. minor Rasnitsyn, 1990 & Neocomian (C) & Siberia & ? \\
\hline
\end{tabular}

* Unfortunately, the holotype of $M$. arctica was destroyed. Should new material eventually be discovered a neotype will be necessary in order to stabilize the application of the name for the species, genus, and even family.

** Cretogonalys is the type genus of the family-group name Cretogonalinae Rasnitsyn, 1977 (nomen imperfectum; recte Cretogonalyinae Rasnitsyn, 1977), which, if the genus is definitively placed in Maimetshidae, would make the former family-group name a junior synonym of the latter family.

Comments. Guyotemaimetsha is most similar to Maimetsha in the absence of cell [2Rs]. It differs in cell [1Rs] being anteriorly petiolate instead of sessile, the hind wing with a free apex of $\mathrm{Cu}$, the absence of a medial line on the vertex, and the presence of tarsal plantulae in females. 


\section{Guyotemaimetsha enigmatica Perrichot, Nel \& Néraudeau, 2004a}

http://species-id.net/wiki/Guyotemaimetsha_enigmatica

Figs $1-4$

Guyotemaimetsha enigmatica Perrichot, Nel \& Néraudeau, 2004a: 159, figs. 1A-B, 2 [ڤ̊].

Type material. Holotype MNHN.F.A30174 (ふ)); paratype MNHN.F.A30175 (ठ̊); in amber collection of the Museum National d'Histoire Naturelle, Paris, France.

Other material examined. Specimens IGR.ARC-1 ( + , missing anterior part of the head and with cuticle somewhat altered by taphonomy), IGR.ARC-309.11 (sex unknown, missing apices of right forewing and metasoma), IGR.ARC-370.7 (= scan ESRF-A-018g, reconstructed, + , in opaque amber), IGR.ARC-378.1 ( $\hat{O}$, missing head, most metasoma and apices of all legs), IGR.ARC-378.2 (scan ERSF A-401-378, not reconstructed; ठ)), IGR.ARC-393.4 (= radiograph ESRF-A-053d, not reconstruct-

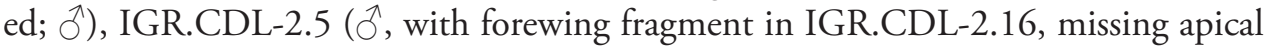
flagellomeres of left antenna; ex collection Arnaud), IGR.CDL-2.33 ( $\widehat{\lambda}$, missing left antenna and apices of right antenna, right forewing, and all legs; ex collection Arnaud). All specimens deposited in the amber collection of the Department of Geosciences of the University Rennes I, France.

Indeterminate specimens. IGR.ARC-171 ( $\hat{\partial}$, missing head, anterodorsal part of metasoma, and forelegs); IGR.ARC-191 (đ̊? ? missing part of the head and mostly obscured, preserved in very dark amber); IGR.ARC-275 ( + , missing parts of mesosoma, left legs, and with metasoma mostly obscured by a bacterial film). These specimens agree in most respects with the definition of $G$. enigmatica but little is preserved and attribution to this species cannot be asserted. All specimens deposited in the amber collection of the Department of Geosciences of the University Rennes I, France.

Type locality. Font-de-Benon quarry, $1 \mathrm{~km}$ east of Archingeay, Charente-Maritime, France.

Stratigraphic horizon. Lithological subunit A1sl-A, Uppermost Albian-Lowermost Cenomanian, middle Cretaceous.

Diagnosis. As for the genus (see above).

Redescription. Male: Integument reddish-brown in color, with dense, minute punctures and fine, decumbent pubescence. Head transverse, with length approximately $0.8 \mathrm{x}$ width; ocelli separated from each other by one ocellar diameter; antennae inserted between compound eyes, closer to each other than to compound eye margin or posterior clypeal margin; scape globular in lateral view, laterally compressed in frontal view, with faintly concave apex; pedicel with sides convex; flagellum with dense coat of short, inclined setae, with first article longest, twice length of pedicel; penultimate article as broad as long; apical article with rounded apex; clypeus transverse, about twice as broad as long, with anterior margin rounded and posterior margin straight; mandibles large, with outer margin convex, overlapping apically when closed; right mandible with basal tooth large, second and third teeth equally smaller, apical tooth 


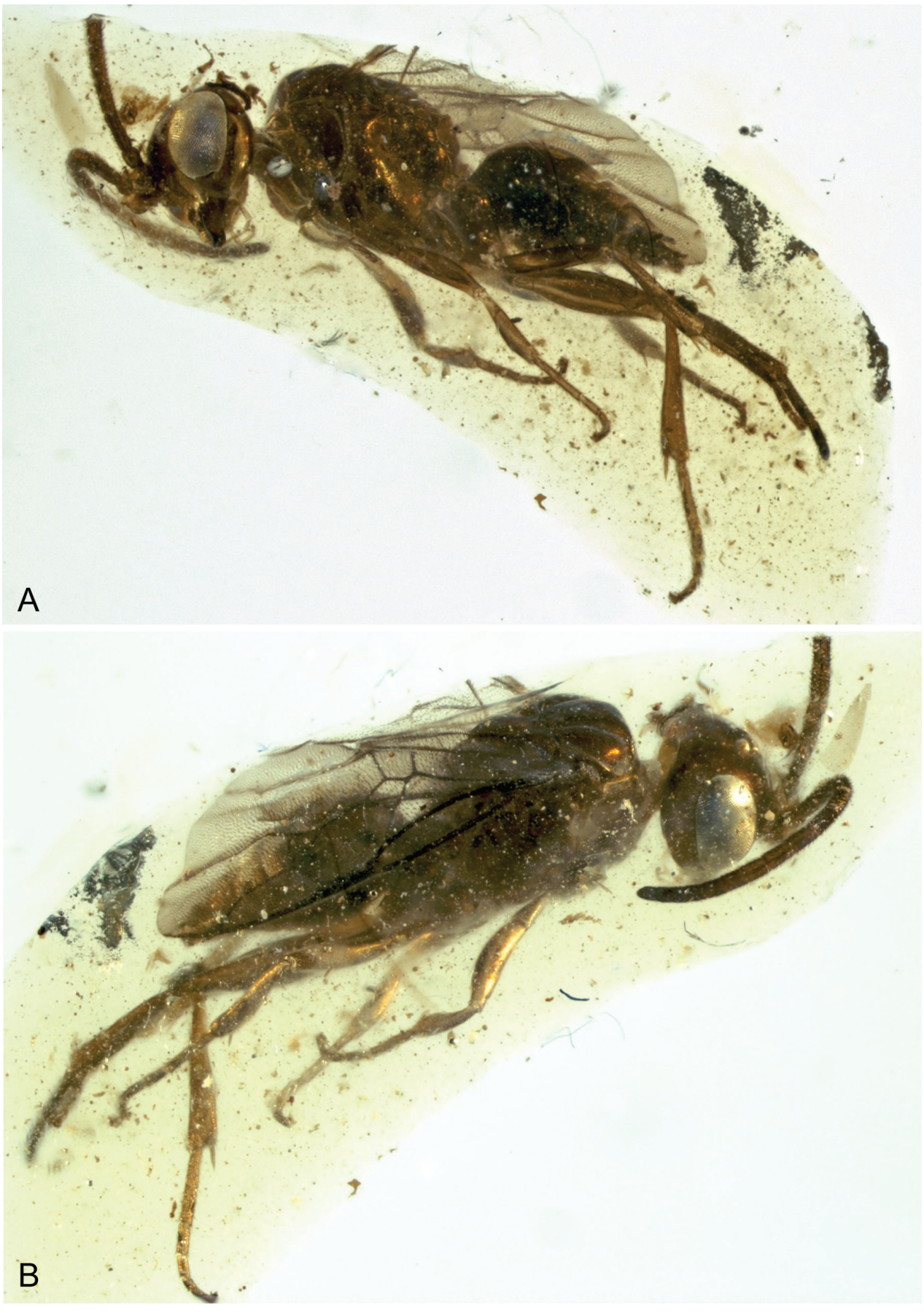

Figure I. Photomicrographs of male of Guyotemaimetsha enigmatica Perrichot et al., 2004a (IGR.CDL2.5) A Left lateral habitus B Right lateral habitus. 


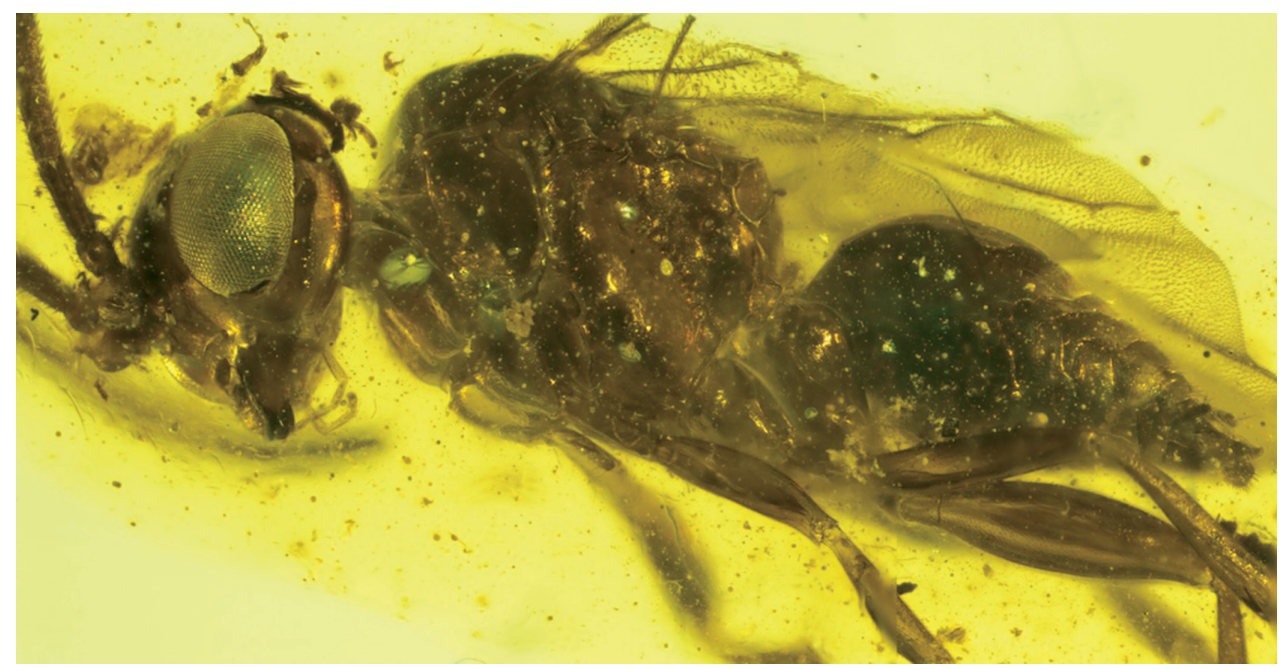

Figure 2. Photomicrograph detail of male of Guyotemaimetsha enigmatica Perrichot et al., 2004a (IGR. CDL-2.5).

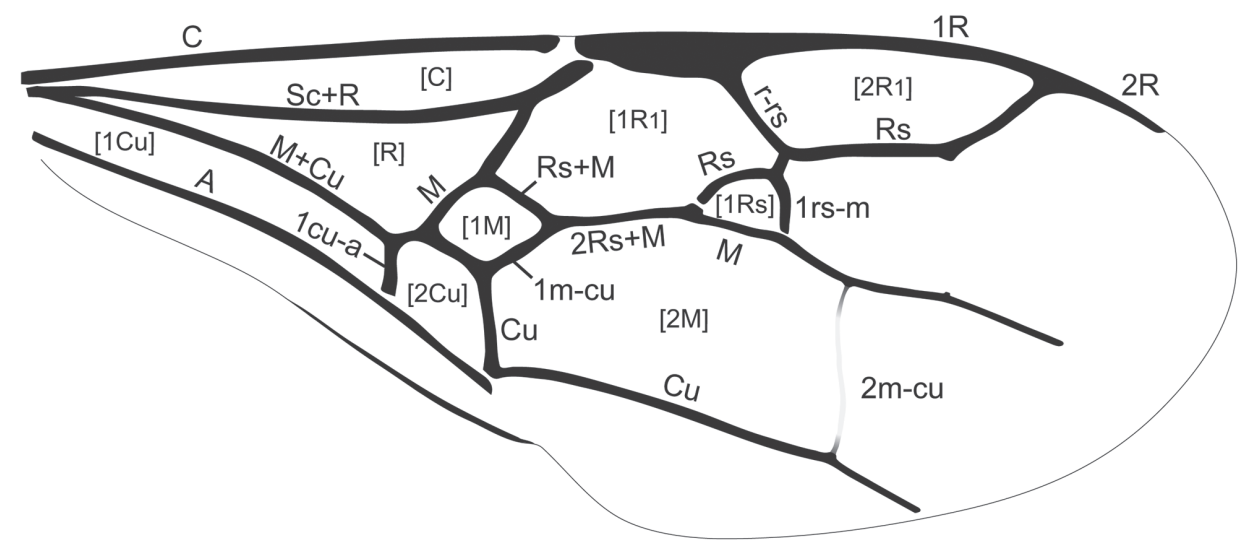

Figure 3. Forewing venation of Guyotemaimetsha enigmatica Perrichot et al., 2004a (paratype MNHNA30175), annotated with vein and cell nomenclature employed herein.

largest; left mandible with basal tooth large, median tooth smallest, apical tooth largest. Mesosoma compact, $0.7 \mathrm{x}$ as high as long; pronotum in dorsal view reduced to a short neck; mesoscutum broader than long, about $0.4 \mathrm{x}$ mesosomal length, abruptely truncate anteriorly to form a flat vertical surface, bordered by a transverse carina at anterolateral corners, with low dorsal convexity; median mesoscutal sulcus crenulate, notauli deeply impressed, slightly diverging anteriorly; mesoscutellum with low dorsal convexity, small triangular axillae separated anteriorly by large foveate groove; propodeum areolate, gradually sloping to pronounced posterior lip; meso- and metapleuron with anterior margin foveolate. Forewing hyaline, with costal cell distinctly enlarged 


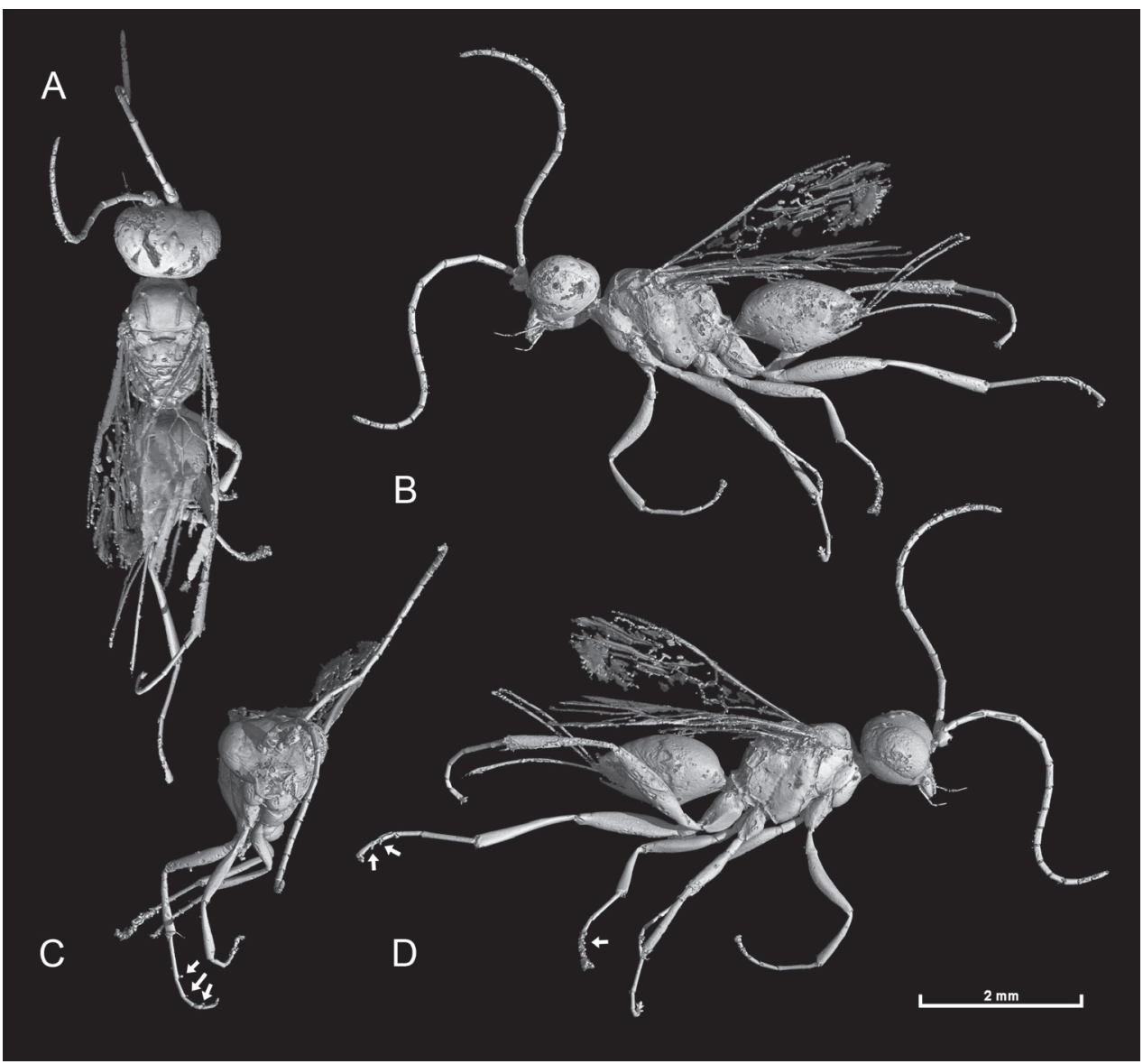

Figure 4. 3D virtual extraction of female of Guyotemaimetsha enigmatica Perrichot et al., 2004a (IGR. ARC-370.7, scan ESRF-A-018g), using PPC-SR $\mu$ CT (voxel size $5.06 \mu \mathrm{m}$, propagation distance $990 \mathrm{~mm}$, $30 \mathrm{keV})$ A Dorsal habitus B Left lateral habitus C Facial aspect D Right lateral habitus. The arrows indicate tarsal plantulae.

around midlength; Rs junction with $\mathrm{Sc}+\mathrm{R}$ forming an acute angle; cell [1M] with vein $\mathrm{M}$ slightly arched, roughly aligned with $\mathrm{Rs}$, vein $\mathrm{Cu}$ shortest, $\mathrm{M}$ and $\mathrm{Rs}+\mathrm{M}$ subequal in length; cells $[1 \mathrm{M}]$ and [1Rs] well distant from each other, separated by long vein $2 \mathrm{Rs}+\mathrm{M} ; 2 \mathrm{Cu}$ significantly longer than $1 \mathrm{Cu}$ and $1 \mathrm{~m}-\mathrm{cu} ; \mathrm{M}$ and $\mathrm{Cu}$ nebulous at apex, reaching wing margin; $2 \mathrm{~A}$ fading to nebulous vein posterior of $[2 \mathrm{Cu}]$. Hind wing with $\mathrm{Sc}+\mathrm{R}, \mathrm{R}, \mathrm{M}+\mathrm{Cu}, \mathrm{Cu}$, and $\mathrm{A}$ tubular, other veins nebulous; $\mathrm{Sc}+\mathrm{R}$ and $\mathrm{R}$ more heavily sclerotized than $\mathrm{M}+\mathrm{Cu}, \mathrm{Cu}$, and $\mathrm{A}$; $\mathrm{Cu}$ fading to nebulous vein apically; free apex of $\mathrm{Rs}$ and $\mathrm{Cu}$ short. Metacoxa approximately $1.4 \mathrm{x}$ length of pro-and mesocoxae, all with broad bases and distinct apical constriction, in lateral view inserted posteroventrally on mesosoma; metafemur distinctly enlarged around midlength; all tibiae approximately subequal to femora in length, with basitarsus length slightly less than combined length of all subsequent tarsomeres. Metasoma compact, as long as mesosoma; parameres 
trapezoidal, narrowed toward apex, with outer surface slightly convex, with short erect setae around apex; cerci small, spatulate, inserted just anterior to parameres.

Female: Very similar to male but with pedicel cylindrical and each leg with a small plantar lobe (or tarsal plantula) on ventral apex of tarsomeres I-IV; ovipositor approximately as long as metasomal length, apex acute. Integument sculpturing and pubescence not visible, altered on specimen IGR.ARC.1 and not reconstructed in microtomographic scan of specimen IGR.ARC-370.7.

\section{Iberomaimetsha Ortega-Blanco, Perrichot \& Engel, gen. n.} urn:lsid:zoobank.org:act:4AF0B360-B635-4139-B360-FB55DD47179F http://species-id.net/wiki/Iberomaimetsha

Type species. Iberomaimetsha rasnitsyni Ortega-Blanco, Perrichot \& Engel, sp. n.

Diagnosis. Antennae with 16 articles; pedicel straight; notauli parallel; forewing costal cell thinner than pterostigma width; prestigma incrassate, wider than base of $\mathrm{R}$, and about the length of $1 \mathrm{Rs}$ (distinctly separated from pterostigma); pterostigma longer than distance from base of Rs to base of $2 \mathrm{r}$-rs; cell [2R $]$ short, about $2.4 \mathrm{x}$ longer than wide; cells [1Rs] and [2Rs] present but with 2rs-m slightly sclerotized; extremely light nebulous $2 \mathrm{~m}-\mathrm{cu}$ (only visible playing with light incidence angle); protibial spur biseriate apically.

Etymology. The new genus-group name is a combination of Iberia, referring to the Iberian Peninsula, and Maimetsha, type genus of the family. The name is feminine.

Comments. Iberomaimetsha is well distinguished from Maimetsha and Guyotemaimetsha in the simultaneous presence of cells [1Rs] and [2Rs] (rm cells sensu Rasnitsyn and Brothers 2009); it differs from Afromaimetsha by its parallel notauli (instead of diverging anteriorly); the prestigma is incrassate, clearly wider than basalmost $\mathrm{R}$, not as in Afrapia; the origin of Rs in Iberomaimetsha is well separated from pterostigma, not as close as in Maimetshorapia; the pedicel is straight and not "comma-shaped" as in Ahstemiam (see below); Andyrossia was described from just a forewing but Iberomaimetsha differs clearly in several details, such as the length of cell [2R $]$ (around 2.4 times longer than wide versus 3.6 in Andyrossia), and the width of cell [C] (narrower than pterostigmal width in Iberomaimetsha versus wider in Andyrossia).

\section{Iberomaimetsha rasnitsyni Ortega-Blanco, Perrichot \& Engel, sp. n.} urn:1sid:zoobank.org:act:96249E3D-C395-48CC-BB76-AB746B0F8B4E http://species-id.net/wiki/Iberomaimetsha_rasnitsyni

Figs 5-7

Type material. Holotype MCNA 9928 (ㅇ); paratype MCNA 8765 (ठึ). All specimens deposited in the Museo de Ciencias Naturales de Álava, Vitoria-Gasteiz, Spain.

Type locality. Peñacerrada I, Moraza, Burgos Province, Basque-Cantabrian Basin, Spain. 


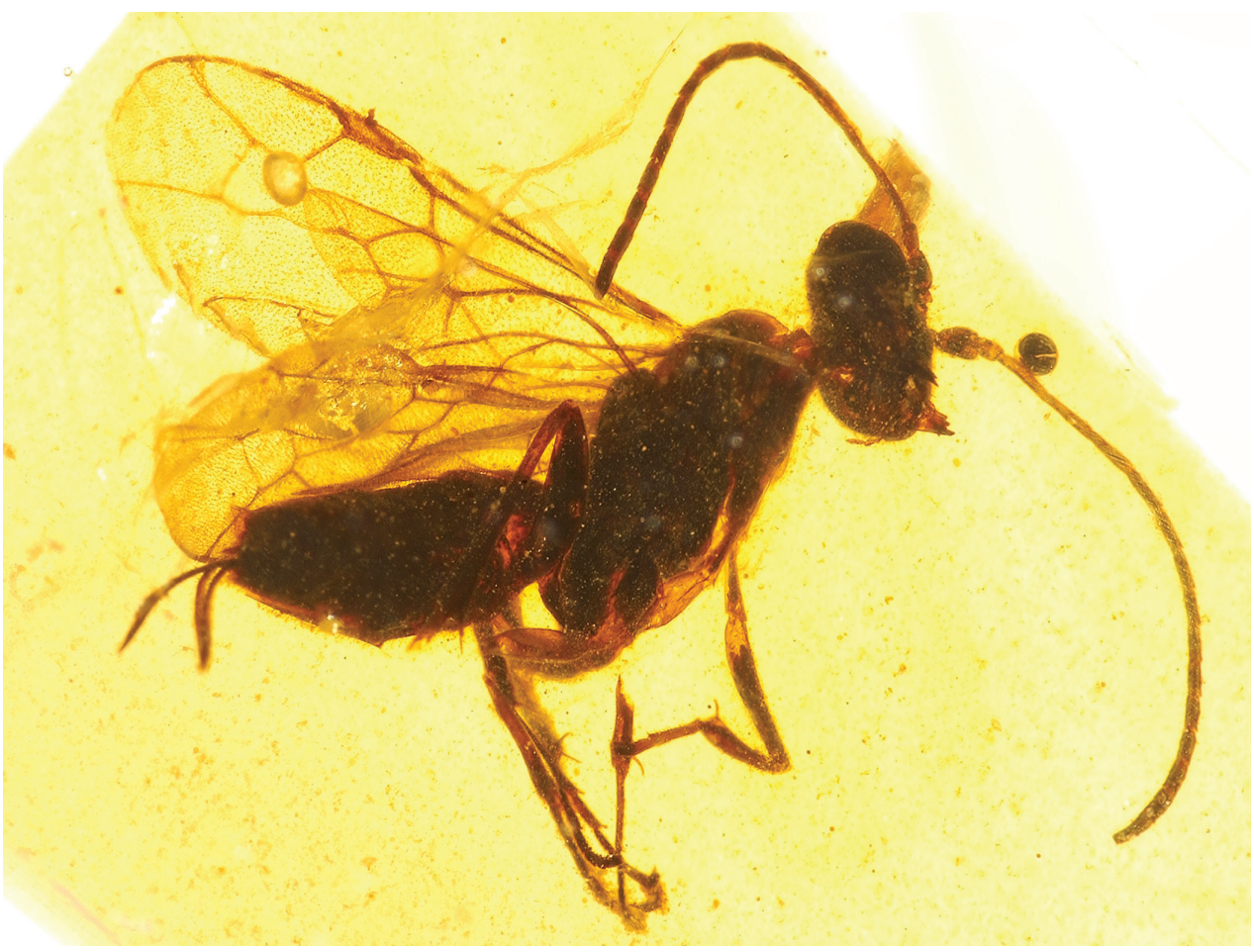

Figure 5. Photomicrograph of holotype female of Iberomaimetsha rasnitsyni Ortega-Blanco, Perrichot, and Engel gen. et sp. n. (MCNA 9928).

Stratigraphic horizon. Escucha Formation, Lower Albian, Lower Cretaceous.

Diagnosis. Mandibles moderately large, each with three teeth, with almost straight margins and teeth (when mandibles opened, teeth facing forward, not curved inward); all flagellomeres of similar length (gradual slight reduction of length); protibial distal margin without comb of stiff setae; tarsal plantulae present on female; cell [1M] about as large as cell $[2 \mathrm{Cu}]$, both almost square or rhomboidal; $2 \mathrm{Rs}+\mathrm{M}$ much shorter than $1 \mathrm{~m}-\mathrm{cu}$ and shorter than cell [1Rs]; apicalmost sector of $\mathrm{Cu}$ arising at midlength of cell [2Cu]; metasoma elongate, about as long as remainder of body; female ovipositor with apex of second valvula 4-toothed.

Description. Female (holotype): Body length $2.8 \mathrm{~mm}$. Head rounded in anterior view, length $0.4 \mathrm{~mm}$, width $0.85 \mathrm{~mm}$; compound eyes not especially bulging, oval, large, well separated by $0.43 \mathrm{~mm}$ dorsally; basal part of palps not visible but maxillary palps with at least five palpomeres; labial palps with at least three palpomeres; slight, triangular, supra-antennal elevation above torulus, intertorular area flattened; toruli closer to each other than to inner margin of compound eyes; antennae $2.4 \mathrm{~mm}$ in length, inserted on frons below midpoint of compound eyes; scape and pedicel short and globular, flagellomeres cylindrical; lengths of antennomeres as follows (all in $\mathrm{mm}$ ): scape 0.15 , pedicel 0.10 , flagellomeres $0.22,0.20$, 


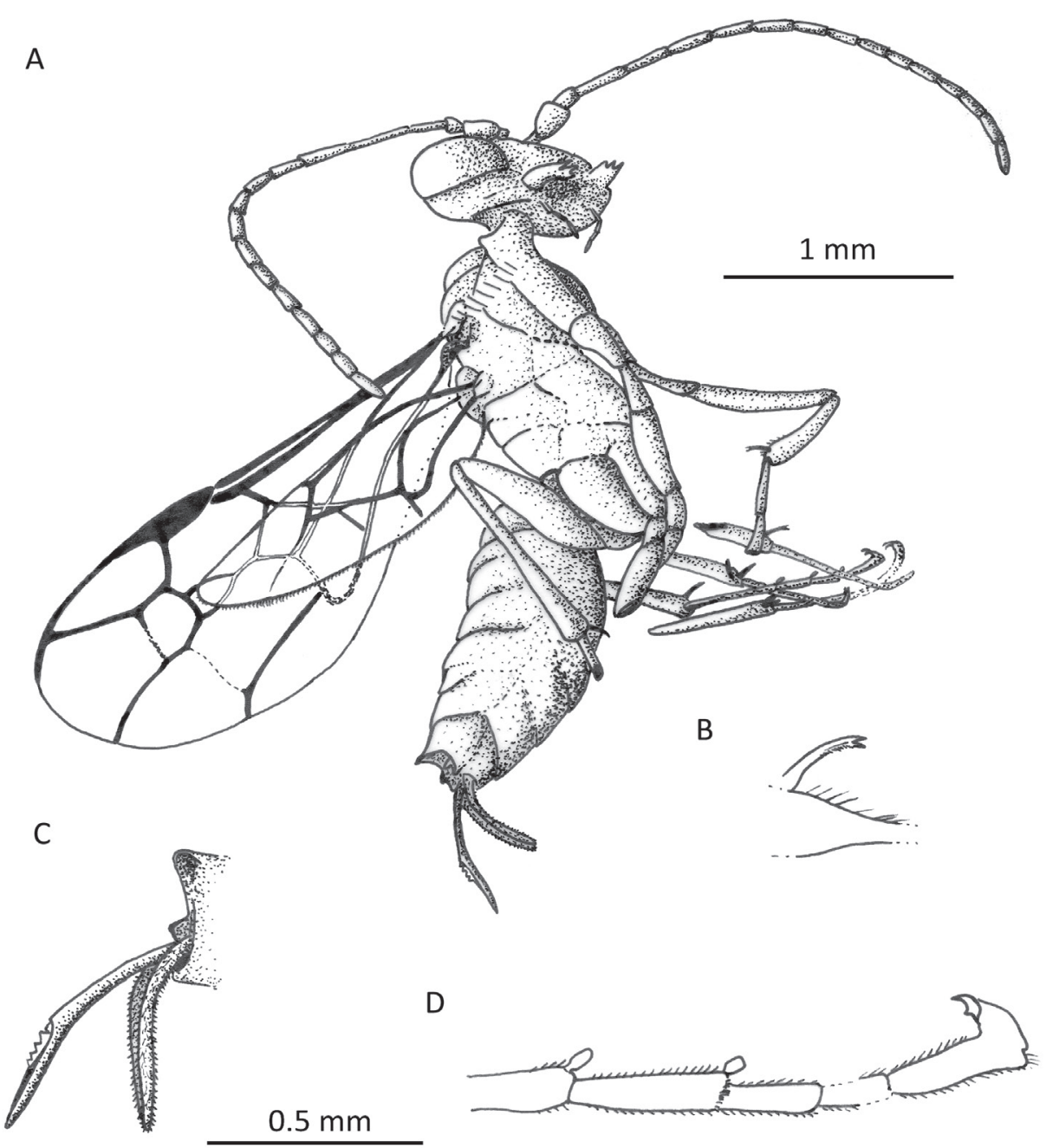

Figure 6. Iberomaimetsha rasnitsyni Ortega-Blanco, Perrichot, and Engel gen. et sp. n. (MCNA 9928) A Habitus diagram of holotype female B Detail of tibial spur C Detail of metasomal apex D Detail of metatarsus showing tarsal plantulae.

$0.20,0.20,0.18,0.15,0.14,0.14,0.12,0.12,0.12,0.12,0.12,0.15$; malar space short, $0.15 \mathrm{~mm}$ in length. Mesosoma only laterally visible, $1.15 \mathrm{~mm}$ in length; pronotum $0.20 \mathrm{~mm}$ in length; mesoscutum $0.35 \mathrm{~mm}$ in length; mesoscutellum strongly convex, $0.30 \mathrm{~mm}$ in length; propodeum slightly rugose, $0.30 \mathrm{~mm}$ in length. Only left mid and hind legs are complete, but foreleg can be reconstructed by mixing right and left parts; no visible division of metatrochantellus; tarsi pentamerous, tarsomeres I-IV each with apicoventral plantar lobe (well visible on left metatarsus: Figs 5, 6D); pretarsal claws with small preapical tooth; leg measure- 


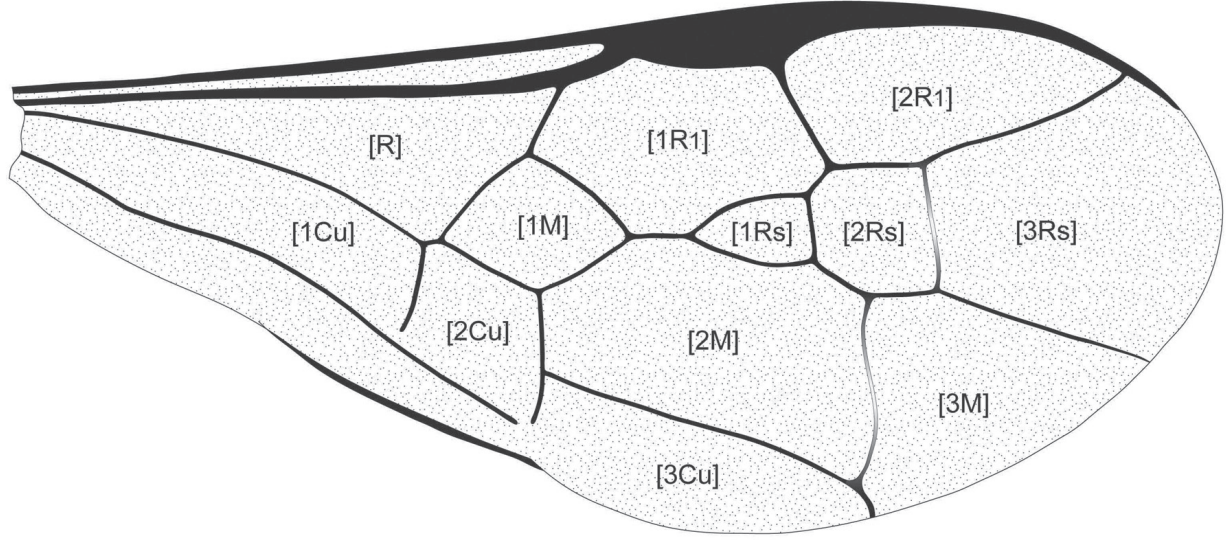

[C]

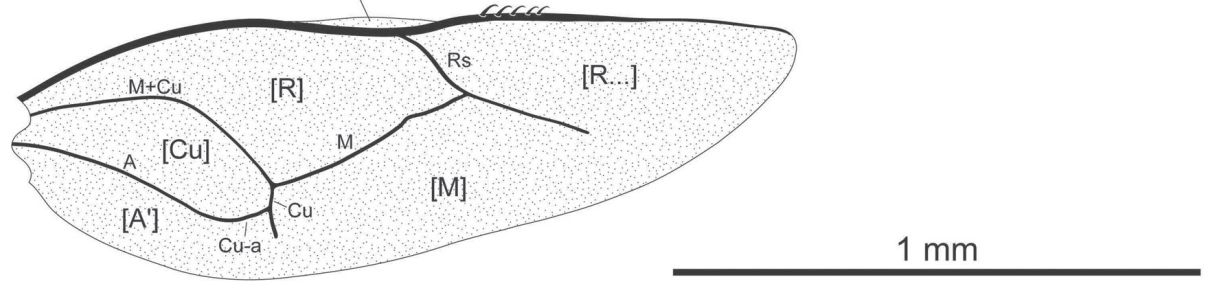

Figure 7. Wing venation of Iberomaimetsha rasnitsyni Ortega-Blanco, Perrichot, and Engel gen. et sp. n. (MCNA 9928), annotated with cell nomenclature employed herein.

ments (all in $\mathrm{mm}$ ): profemur (with protrochantellus) 0.85 , protibia 0.50 , protarsomeres I-V 0.30/0.15/0.12/?/?; mesofemur 0.75 , mesotibia 0.72 , mesotarsomeres $0.32 / 0.15 / 0.10 / 0.07 / 0.12$; metafemur 0.95 , metatibia 0.90 , metatarsomeres $0.38 / 0.15 / 0.10 / 0.08 / 0.14$. Forewing hyaline, length $2.4 \mathrm{~mm}$, maximum width $0.95 \mathrm{~mm}$, densely covered by microtrichia; all veins tubular except for nebulous crossveins $2 \mathrm{rs}-\mathrm{m}$ and $2 \mathrm{~m}$-cu, thus only cells [2Rs] and [2M] pseudo-opened apically (Fig. 7A); 1 rs-m not aligned with r-rs; $2 \mathrm{~m}$-cu curved at each distal end; veins $\mathrm{M}$ and $\mathrm{Cu}$ reaching wing margin, with distal end of $\mathrm{Cu}$ strongly bent posteriorly; cell $\left[1 \mathrm{R}_{1}\right]$ longer than both cells $[1 \mathrm{Rs}]+[2 \mathrm{Rs}]$; cell $[1 \mathrm{Rs}]$ about half the surface of cells $[1 \mathrm{M}]$ and $[2 \mathrm{Rs}]$; vein $\mathrm{r}$-rs emerging at two-thirds from base of pterostigma; cell $\left[2 \mathrm{R}_{1}\right]$ short, with vein Rs slightly anteriorly bent distad $2 \mathrm{rs}-\mathrm{m}$. Hind wing hyaline and densely covered by microtrichia, length $1.65 \mathrm{~mm}$, maximum width 0.45 $\mathrm{mm}$; five strong hamuli present on costal vein in distal half of wing (Fig. 7B); distal sections of veins $\mathrm{Rs}$ and $\mathrm{Cu}$ reaching nebulous wing margin; vein $\mathrm{A}$ lost beyond $\mathrm{cu}-\mathrm{a}$. Metasoma pedunculate, elongate and globoid, length $1.3 \mathrm{~mm}$, greatest height $0.5 \mathrm{~mm}$; sterna hard, convex; no apparent metasomal armature on sternum II or III; cerci very short; ovipositor moderately exserted, first valvula $0.65 \mathrm{~mm}$ long (as preserved), second valvula $0.35 \mathrm{~mm}$ long, apically with four dorsal teeth, with sheaths covered by very short, sparse setae (Figs. 4, 5A, 5C). 
Male: Very similar to female except in following minor differences: Body length $3.63 \mathrm{~mm}$; tarsi without plantar lobes; metasoma slightly longer than mesosoma.

Etymology. The specific epithet is a patronym honoring Prof. Alexandr P. Rasnitsyn for his numerous important contributions to the study of Hymenoptera and his generous friendship with the authors.

\section{Iberomaimetsha nihtmara Ortega-Blanco, Delclòs \& Engel, sp. n.} urn:lsid:zoobank.org:act:8E3C73D0-4CE1-4910-9DE6-45A0D3BC2F1D http://species-id.net/wiki/Iberomaimetsha_nihtmara

Figs 8-10

Type material. Holotype MCNA 13049 (?); paratypes MCNA 8758(q?), MCNA 8790 (ふ̊), MCNA 9373 (?), MCNA 9918 (ㅇ), and MCNA 10732 (?). All specimens deposited in the Museo de Ciencias Naturales de Álava, Vitoria-Gasteiz, Spain.

Type locality. Peñacerrada I, Moraza, Burgos Province, Basque-Cantabrian Basin, Spain.

Stratigraphic horizon. Escucha Formation, Lower Cretaceous, Lower Albian.

Diagnosis. Mandibles distinctly large, exserted, asymmetrical, right 4-toothed, left 3-toothed, arched inwards (teeth pointing toward teeth of opposite mandible); basal flagellomeres (from F1 to F3-4) distinctly larger than apical flagellomeres (F1-F4 about $2-1.5 \times$ the length of F7-F14); protibial distal margin with a comb of stiff setae; cell $[1 \mathrm{M}]$ square or rhomboidal, distinctly smaller than $[2 \mathrm{Cu}]$ which has a short but distinct connection between $1 \mathrm{M}+\mathrm{Cu}$ and $\mathrm{M}$ (then, $[2 \mathrm{Cu}]$ composed by five aristae); $2 \mathrm{Rs}+\mathrm{M}$ longer than $1 \mathrm{~m}-\mathrm{cu}$ and longer than cell [1Rs]; apicalmost sector of $\mathrm{Cu}$ arising from almost apical posterior margin of [2Cu]; metasoma moderately short, as long as mesosoma.

Description. Body length (from paratypes, as incomplete metasoma in holotype) around $2.55-2.61 \mathrm{~mm}$. Head rounded in anterior view, length $0.41 \mathrm{~mm}$, width $0.68 \mathrm{~mm}$ with a short occipital carina and apparently some polygonal dorsal sculpture; compound eyes not bulging, slightly oval, separated dorsally by 0.39 $\mathrm{mm}$; toruli about at same distance to inner margin of compound eyes and each other; antennae $2.54 \mathrm{~mm}$ in length, inserted on frons below midpoint of compound eyes; scape and pedicel short and globular, flagellomeres cylindrical; lengths of antennomeres as follows (all in $\mathrm{mm}$ ): scape 0.12, pedicel 0.09, flagellomeres $0.29,0.28,0.27,0.23,0.20,0.18,0.15,0.14,0.12,0.12,0.11,0.11,0.10,0.12$; malar space short, length approximately $0.11 \mathrm{~mm}$. Mesosoma (dorsal view) 0.95 $\mathrm{mm}$ in length; pronotum not distinct dorsally; mesoscutal length $0.27 \mathrm{~mm}$, with parallel notauli and longitudinal medial line, all three present as linear series of grooves more than well-delimited lines (Fig. 9); axillae wide and long, well distinct, separating completely mesoscutellum and mesoscutum; mesoscutellum distinctly convex, length $0.22 \mathrm{~mm}$; propodeum $0.29 \mathrm{~mm}$ in length, areolate (seen in paratype MCNA 8790). Legs distinctly elongate; division of trochantellus not 

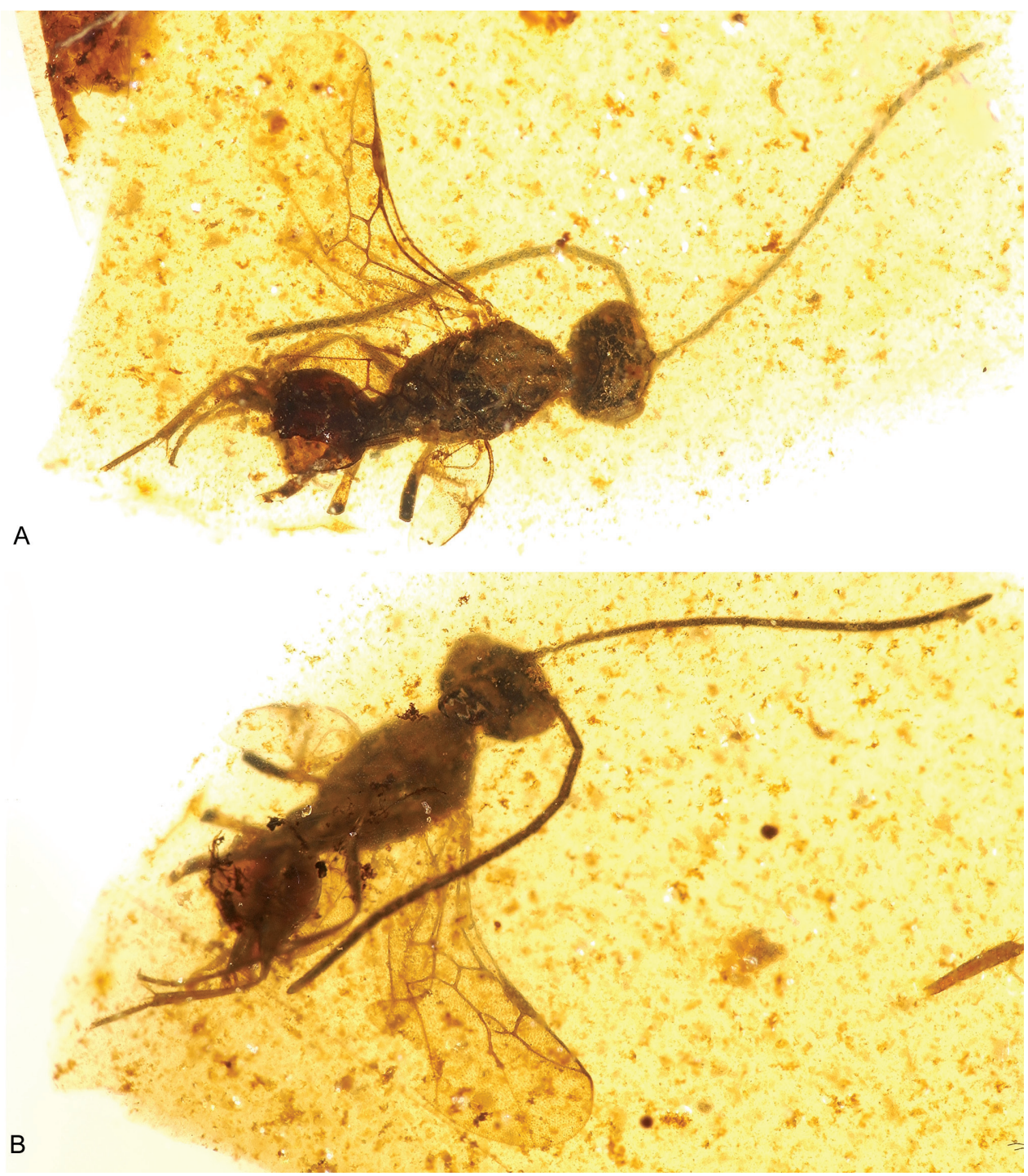

Figure 8. Photomicrographs of holotype of Iberomaimetsha nibtmara Ortega-Blanco, Delclòs, and Engel sp. n. (MCNA 13049) A Dorsal aspect B Ventral aspect.

visible; tarsi with no plantar lobes visible; leg measurements (all in $\mathrm{mm}$ ): profemur 0.82, protibia 0.46, protarsomeres I-V 0.34/0.15/0.10/0.09/0.10; mid-legs very poorly preserved but apparently with mesofemur 0.68 , mesotibia ?, mesotarsomeres 0.24/0.12/0.10/?/?; metafemur 1.0, metatibia 0.83 , metatarsomeres $0.46 / 0.20 / 0.15 / 0.09 / 0.12$. Forewing hyaline, length $2.1 \mathrm{~mm}$, maximum width $0.80 \mathrm{~mm}$, densely covered by microtrichia; all veins tubular except for nebulous $2 \mathrm{rs}-\mathrm{m}$ and $2 \mathrm{~m}-\mathrm{cu}$, thus, only cells $[2 \mathrm{Rs}]$ and $[2 \mathrm{M}]$ pseudo-opened apically (Figs 9, 10); 1 rs-m not aligned with r-rs; $2 \mathrm{~m}$-cu curved S-like; veins $\mathrm{M}$ and $\mathrm{Cu}$ reach- 


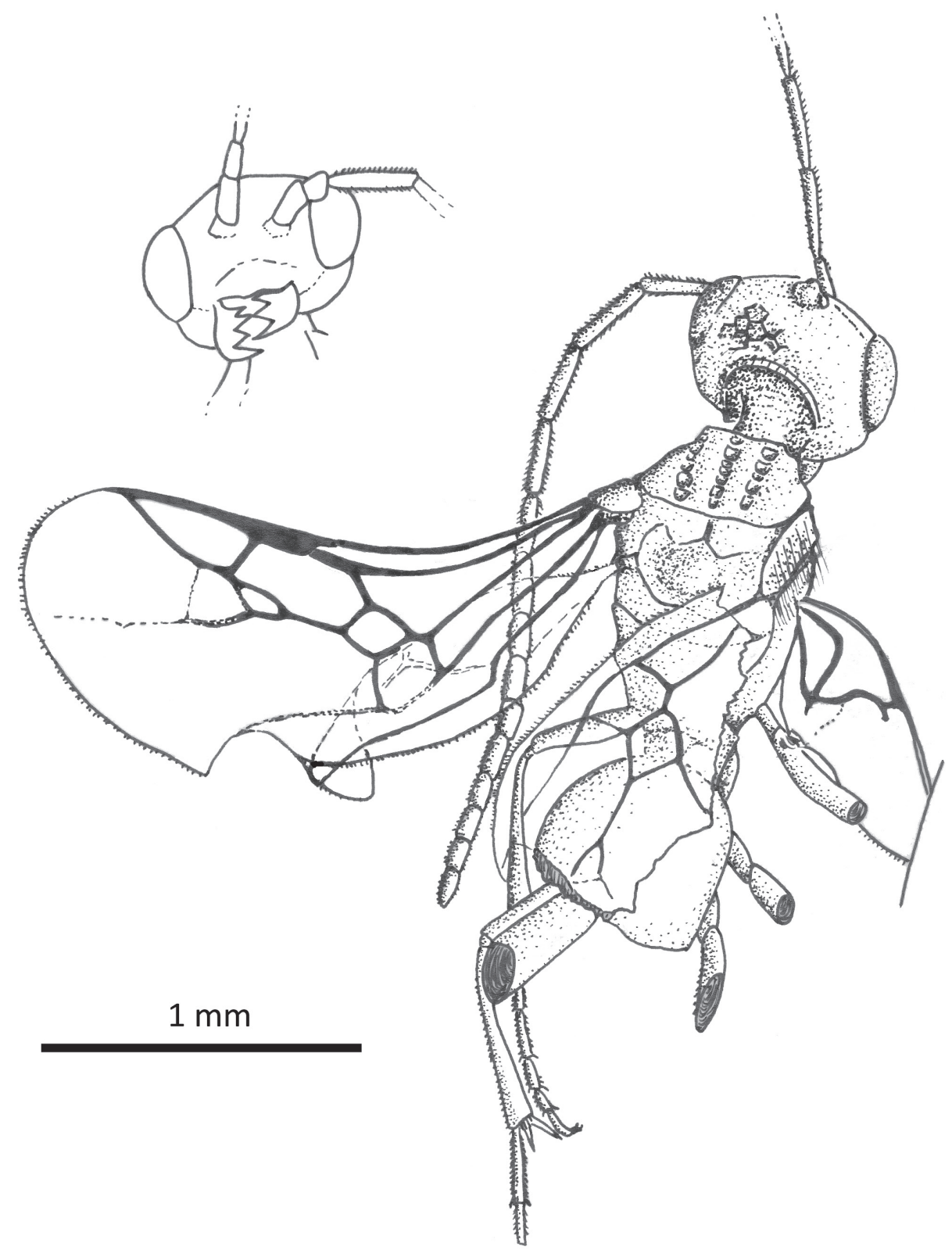

Figure 9. Habitus diagram of holotype of Iberomaimetsha nihtmara Ortega-Blanco, Delclòs, and Engel sp. n. (MCNA 13049), with inset of facial aspect.

ing wing margin (although $\mathrm{M}$ somewhat nebulous), with apicalmost sector of $\mathrm{Cu}$ slightly angled posteriorly; cell $\left[1 \mathrm{R}_{1}\right]$ longer than both cells $[1 \mathrm{Rs}]+[2 \mathrm{Rs}]$; cell [1Rs] almost $3 / 4$ the surface of cell $[1 \mathrm{M}]$ and almost half of [2Rs]; vein $\mathrm{r}$-rs emerging at two-thirds from base of pterostigma; cell $\left[2 \mathrm{R}_{1}\right]$ short, with vein Rs slightly anteri- 


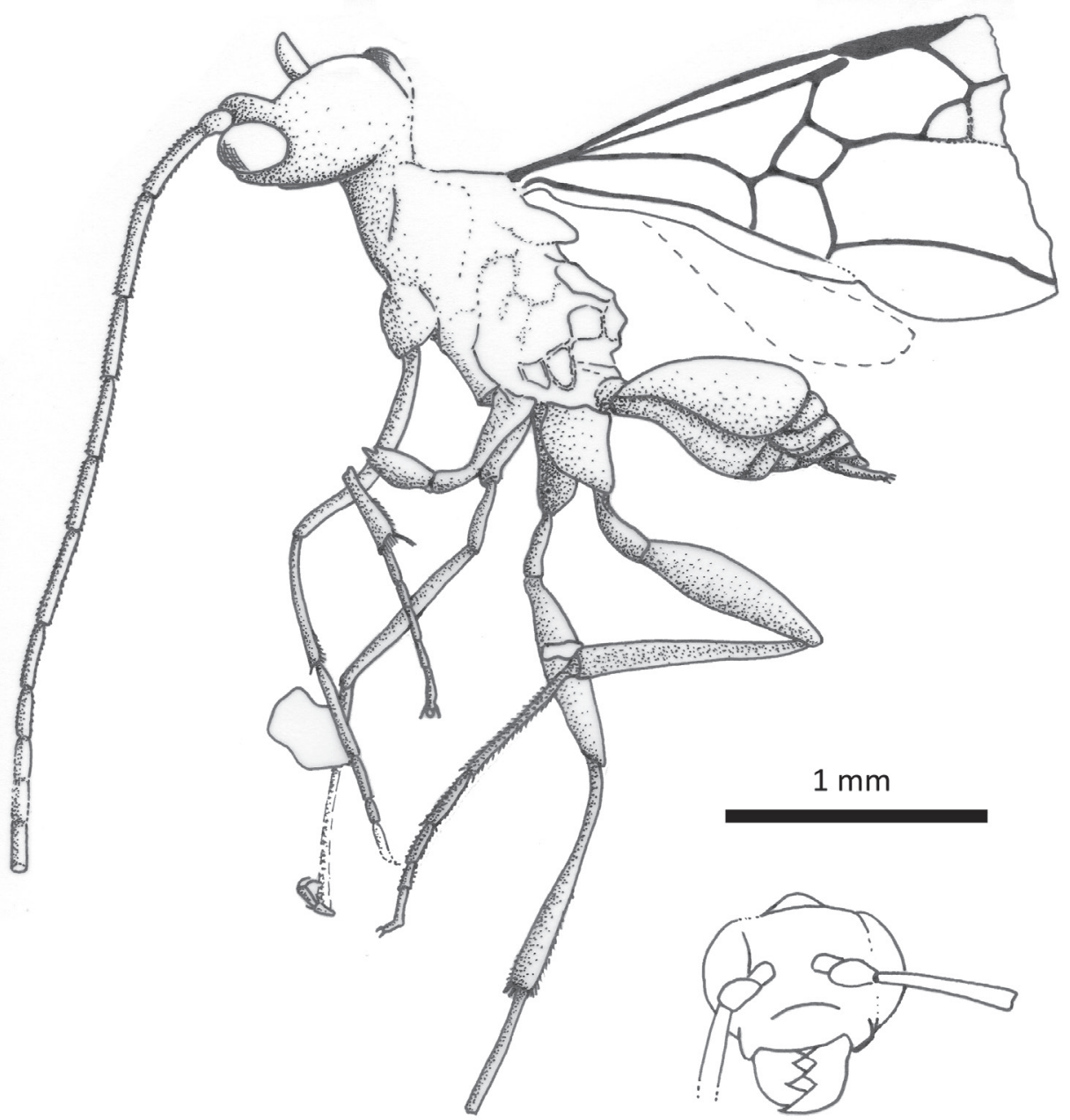

Figure 10. Habitus diagram of male paratype of Iberomaimetsha nihtmara Ortega-Blanco, Delclòs, and Engel sp. n. (MCNA 8790), with inset of facial aspect.

orly bent distad 2rs-m. Hind wing difficult to observe, hyaline and densely covered by microtrichia, length approximately $1.22 \mathrm{~mm}$, maximum width approximately $0.41 \mathrm{~mm}$; three strong hamuli present on costal vein in distal half of wing. Metasoma (checked on paratype MCNA 8790) pedunculate, short and slightly flattened, length $0.98 \mathrm{~mm}$, greatest height $0.41 \mathrm{~mm}$; sterna hard, convex; no apparent metasomal armature on sternum II or III.

Male: Parameres spatulate, with apparently three short stiff setae apically (Fig. 10).

Etymology. The specific epithet is a noun in apposition and is the Anglo-Saxon word for nightmare, in reference to the terrifying appearance of the species in frontal view and with its enlarged mandibles. 
Abiromaimetsha Perrichot, Azar, Nel \& Engel, gen. n. urn:Isid:zoobank.org:act:56912C39-6C5D-4DF9-81A9-1198DE2C1A6B http://species-id.net/wiki/Ahiromaimetsha

Type species. Ahiromaimetsha najlae Perrichot, Azar, Nel \& Engel, sp. n.

Diagnosis. Antennae apparently with 16 articles; pedicel straight; forewing costal cell apically about as wide as pterostigmal width; prestigma not incrassate, not wider than base of $\mathrm{R}$, about as long as $1 \mathrm{Rs}$ (distinctly separated from pterostigma); cell [2R $\mathrm{R}_{1}$ long, nearly $4 \mathrm{x}$ longer than wide; cells $[1 \mathrm{Rs}]$ and $[2 \mathrm{Rs}]$ present, former greatly enlarged; $2 \mathrm{Rs}+\mathrm{M}$ absent owing to confluence of $1 \mathrm{~m}$-cu with $2 \mathrm{Rs}$; $1 \mathrm{rs}-\mathrm{m}$ exceptionally minute (Figs 11, 12D); 2rs-m completely sclerotized; protibial spur bifurcate apically; female tarsi with apicoventral plantar lobes.

Etymology. The new genus-group name is a combination of Ahirom, Phoenician king of Byblos (ca. $1000 \mathrm{BC}$ ) whose sarcophagus bears the oldest inscription in the Phoenician alphabet, and Maimetsha, type genus of the family. The name is considered to be feminine.

Comments. Ahiromaimetsha can be distinguished most easily from other genera by the effective absence of $2 \mathrm{Rs}+\mathrm{M}$ owing to the confluence of $1 \mathrm{~m}$-cu with the second free abscissa of Rs. Like I. rasnitsyni and A. joyceae, Ahiromaimetsha najlae has a large cell [1Rs] but even more so than in the aforementioned species and, unlike I. rasnitsyni, the prestigma is not incrassate.

\section{Abiromaimetsha najlae Perrichot, Azar, Nel \& Engel, sp. n.} urn:lsid:zoobank.org:act:50E62250-CD58-4CBC-A60F-EEBCBF028F38 http://species-id.net/wiki/Ahiromaimetsha_najlae Figs $11-12$

Type material. Holotype MKN-1A ( 9 ), collection Azar, provisionally deposited in the Muséum National d'Histoire Naturelle, Paris, France.

Type locality. Maknouniyyeh, Caza Jezzine, Mouhafazit Loubnan Al-Janoubi (South Lebanon district), Lebanon.

Stratigraphic horizon. Neocomian (Valanginian-Lowermost Aptian), Lower Cretaceous.

Diagnosis. As for the genus (see above).

Description. Female: Total body length ca. $5.2 \mathrm{~mm}$. Head nearly rounded in anterior view, length $0.97 \mathrm{~mm}$, width $1.35 \mathrm{~mm}$, finely setose; compound eyes somewhat bulging, oval, large, length $0.78 \mathrm{~mm}$, width $0.62 \mathrm{~mm}$; ocelli positioned on swelling; mandibles strong, asymmetrical, right with four teeth and left with three teeth both with apical tooth largest; maxillary palps well developed, elongate, distinctly longer than mandibles, with six palpomeres; labial palps short, with four palpomeres; antennae partly damaged but complete, with apparently 16 segments 


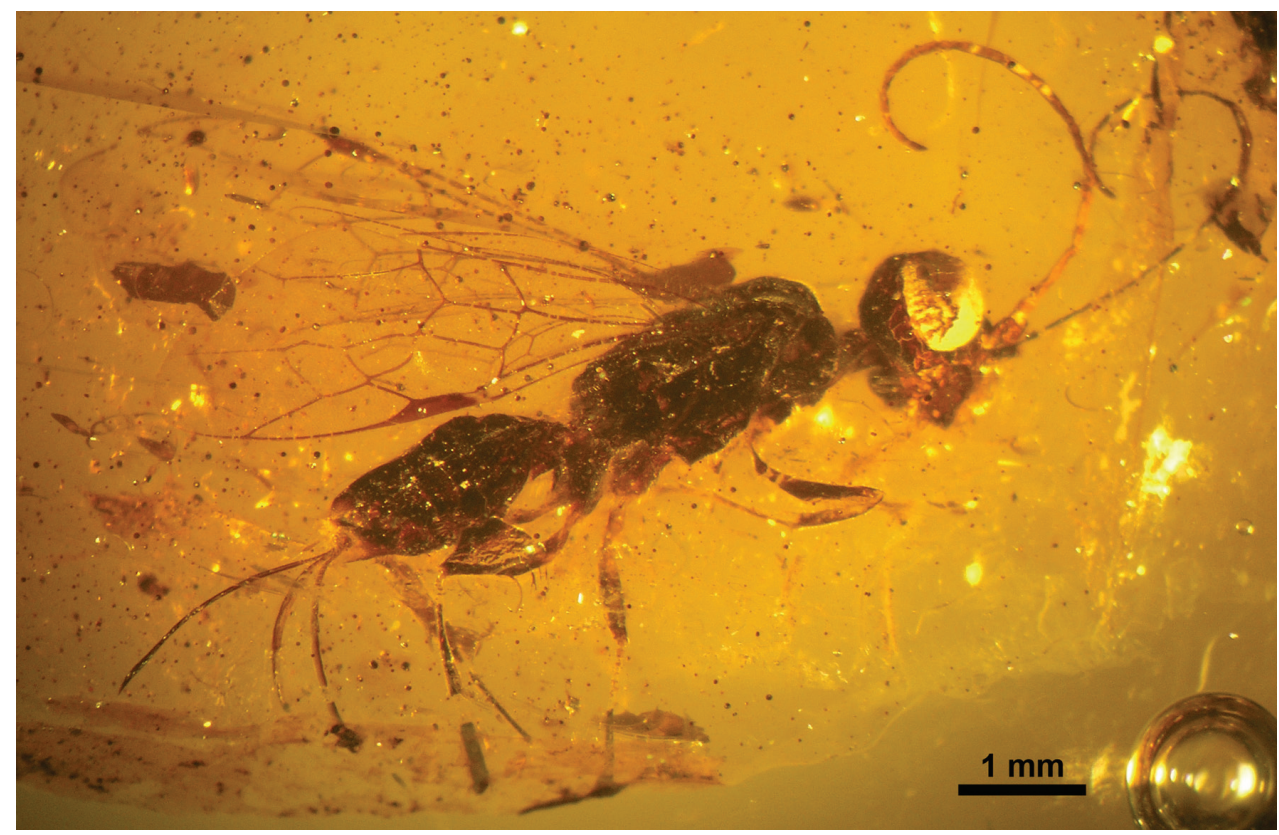

Figure II. Photomicrograph of holotype female of Ahiromaimetsha najlae Perrichot, Azar, Nel, and Engel gen. et sp. n. (MKN-1A).

(some segments have secondary constrictions owing to compression), scape and pedicel short and globulous, flagellomeres cylindrical, length of antennomeres as follows (all in $\mathrm{mm}$ ): scape 0.3 , pedicel 0.16 , flagellomeres $0.47,0.52,0.45,0.34$, $0.32,0.32,0.22,0.17,0.17,0.16,0.16,0.14,0.11,0.11$; antenna with fine setae and sparse sensilla. Mesosomal length $2.21 \mathrm{~mm}$, height $1.09 \mathrm{~mm}$, finely setose but without visible foveae or sculpturing; mesoscutal length $0.71 \mathrm{~mm}$, with strong anterior median depression; mesoscutellum not clearly visible, obscured by wings. Metacoxa with an outer basal extension; metatrochantellus diagonally divided and appearing two-segmented; protibial calcar bifurcate (Fig. 12B), with defined velum and trunk, velum smooth, trunk with spine-like microsculpture, basitarsal comb composed of blunt, flattened pegs; pretarsal claws cleft; leg measurements (all in $\mathrm{mm}$, given for those observable): procoxa 0.21 , protrochanter 0.42 , profemur 0.82 , protibia 0.60 , probasitarsus 0.61 , second protarsomere 0.16 , third protarsomere 0.11 , mesocoxa 0.39 , mesotrochanter 0.55 , mesofemur 0.81 , metacoxa 0.48 , metatrochanter 0.16 , metafemur 1.10 . Wings hyaline, forewing length 4.81 $\mathrm{mm}$, width $1.54 \mathrm{~mm}$; hind wing length $3.12 \mathrm{~mm}$, width $1.15 \mathrm{~mm}$; venation as in figure 12D; five distal hamuli on hind wing. Metasomal length $2.11 \mathrm{~mm}$; height $0.81 \mathrm{~mm}$; metasomal sterna well sclerotized, convex; ovipositor long, length 2.16 $\mathrm{mm}$, with clearly visible denticles at apex (Fig. 12C).

Male: Unknown. 


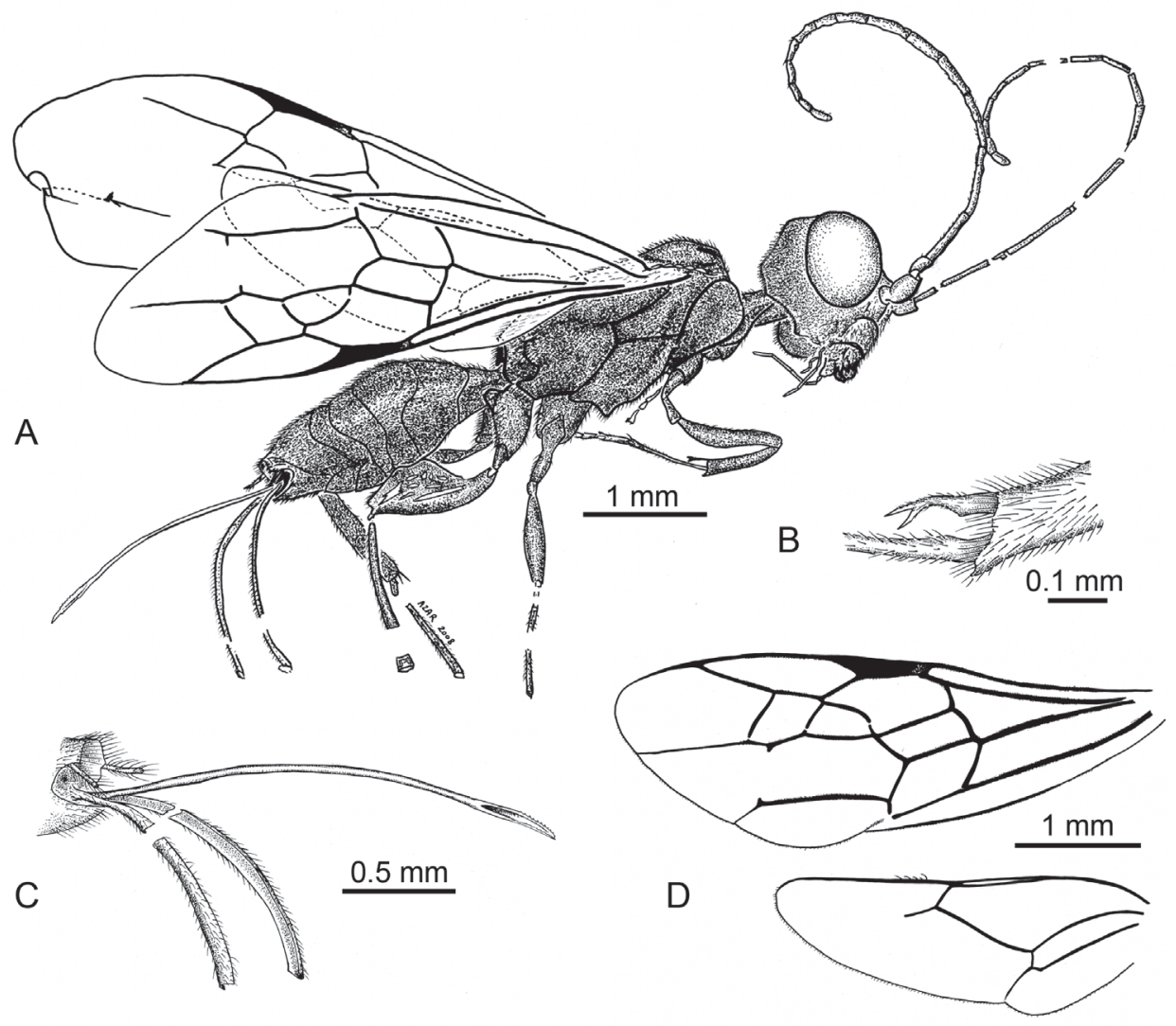

Figure 12. A Habitus diagram of holotype female of Ahiromaimetsha najlae Perrichot, Azar, Nel, and Engel gen. et sp. n. (MKN-1A), with inset of $\mathbf{B}$ fore tibial spine $\mathbf{C}$ ovipositor $\mathbf{D}$ forewing and hind wing venation.

Etymology. The specific epithet is a matronym honoring Dr Najla Zeidane-Gèze, wife of the collector of the holotype.

Ahstemiam McKellar \& Engel, gen. n. urn:lsid:zoobank.org:act:C50729F7-36EC-4AD3-BAB9-6CAE13C8D74E http://species-id.net/wiki/Ahstemiam

Type species. Ahstemiam cellula McKellar \& Engel, sp. n.

Diagnosis. Total body length near $1.2 \mathrm{~mm}$; compound eyes globular and protuberant; fine occipital carina present; pedicel 'comma-shaped' in lateral view, $0.54 \mathrm{x}$ length of scape and inserted deeply into scape's apex; 14 flagellomeres, cylindrical in shape and progressively shortening; maxillary palpus with at least three palpomeres, 
ultimate palpomere with three apical stiff setae, penultimate palpomere with one apical and two mid-body stiff setae; labial palpus apparently with three palpomeres, all short and bearing numerous stiff setae; junction between $S_{c}+R$ and $R s$ very close to pterostigma, $2 \mathrm{~S}_{c}+\mathrm{R}$ shorter than $\mathrm{Rs}$; pterostigma elongate, longer than $\left[2 \mathrm{R}_{1}\right]$, with gradual apical taper; $r-r s$ originating within apical one-third of pterostigmal length; $2 \mathrm{R}$ present as small stub; $[1 \mathrm{M}]$ relatively small, apical corner (junction of $\mathrm{Rs}+\mathrm{M}$ and $1 \mathrm{~m}-$ $\mathrm{cu}$ crossvein) positioned posterior to pterostigma; [1Rs] triangular, bounded by very thin $\mathrm{M}$ posteriorly, 2Rs and 1rs-m forming anterior and apical margins of cell, both fade to become nebulous throughout most of cell's length; first apparent metasomal segment much shorter than cell $\left[2 \mathrm{R}_{1}\right]$.

Etymology. The new genus-group name is the inverse of the type genus, Maimet$s h a$, and is considered a meaningless euphonious combination of letters. The name is designated to be feminine in gender.

Comments. Ahstemiam is most similar to Maimetshorapia. The new genus differs in the presence of a prestigma (abscissa of R between $1 \mathrm{Rs}$ and pterostigma) that is only slightly inflated (as opposed to distinctly incrassate) and faded apically, as well as a first apparent metasomal tergum that is much shorter than cell $\left[2 \mathrm{R}_{1}\right]$. The nebulous veins bordering the posterior edges of cell [1Rs], as well as the small size of the cell itself, are distinct among known members of the family Maimetshidae.

\section{Ahstemiam cellula McKellar \& Engel, sp. n.} urn:lsid:zoobank.org:act:E2504362-00B5-4DF0-8047-2B59E46BBBA0 http://species-id.net/wiki/Ahstemiam_cellula Figs $13-14$

Type material. Holotype CNC-CAS 1038 (ठ) (Fig 13). Deposited in Canadian National Collection of Insects and Arthropods, Ottawa, Ontario, Canada.

Type locality. Grassy Lake, Alberta, Canada.

Stratigraphic horizon. Uppermost Foremost Formation, Campanian, Upper Cretaceous.

Diagnosis. As for the genus (see above).

Description. Male (holotype): Body color apparently dark brown, with paler brown antennae and femora, and yellow legs distal to femora (Fig. 13). Head slightly distorted in type specimen, appearing broad (transverse) and foreshortened (exsagittal), with length $0.57 \times$ width; ventral margin of gena with prominent notches, more so adjacent to mandibles; frons deeply impressed, antennal bases inserted in shallow depression between compound eyes (Fig. 13); vertex with sparse, short, inclined setae; scape taphonomically distorted, in lateral view, elongate and narrow basally with pronounced apical flare, and concave apex (Fig. 14); pedicel with row of midlength stiff setae inclined upon ventral margin; apical flagellar article slightly wider than preceding articles, and tapering to bluntly-rounded apex; flagellum with dense coat of short, curled setae in various orientations. Mesoscutum with low dorsal convexity, appar- 

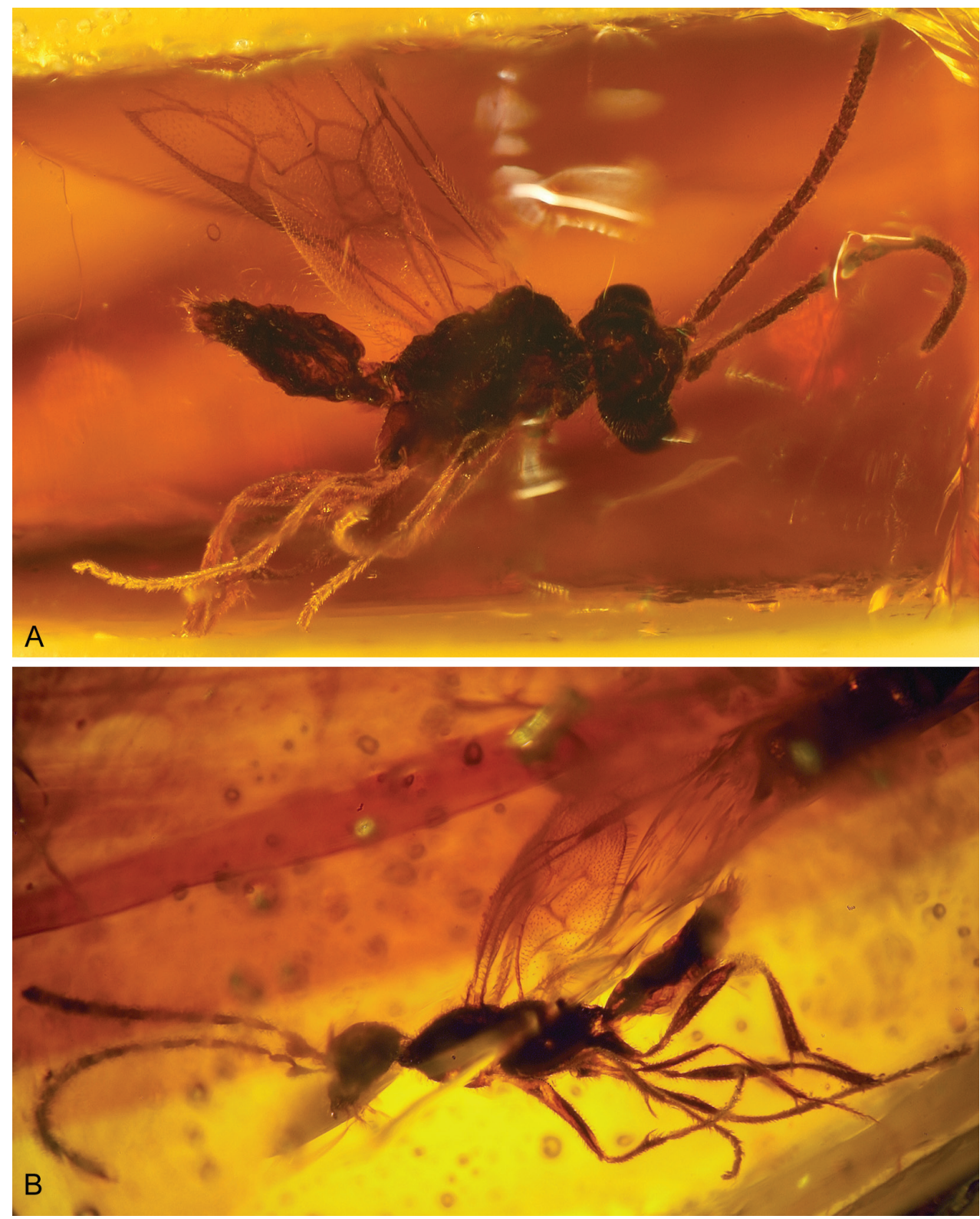

Figure 13. Photomicrographs of holotype male of Ahstemiam cellula McKellar and Engel gen. et sp. $\mathrm{n}$. (CNC-CAS 1038) A Oblique ventral view B Lateral view.

ently near one-half of mesosomal length; mesoscutellum with low dorsal convexity, overhanging metanotum slightly, bearing numerous short, inclined setae; metanotum with prominent ridge along posterior margin which projects posterodorsally over propodeum; propodeum gradually sloping to pronounced posterior lip. Forewing at least $0.96 \mathrm{~mm}$ in length and $0.42 \mathrm{~mm}$ in width, hyaline with microtrichial vestiture and 


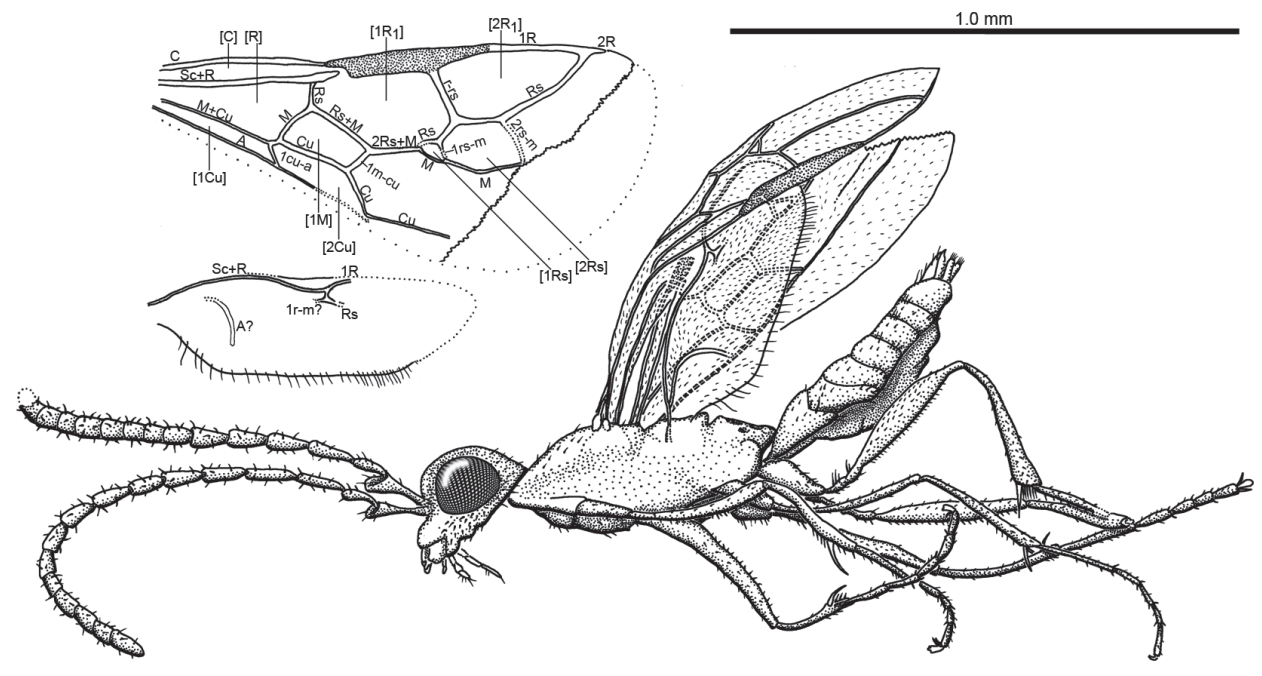

Figure 14. Habitus diagram male of Ahstemiam cellula McKellar and Engel gen. et sp. n. (CNC-CAS 1038), with inset of forewing and hind wing venation.

pterostigma pale brown, like tubular veins in wing; $\mathrm{Sc}+\mathrm{R}$ slightly thicker than other veins, narrowing basally but expanding apical to junction with Rs; fusion of Rs and $\mathrm{M}$ angled, veins not parallel to each other; 2rs-m apparently nebulous throughout its course, but preserved in only one wing, which appears taphonomically affected in this region; apex of $\mathrm{M}$ not preserved in type specimen; $2 \mathrm{Cu}$ significantly longer than $1 \mathrm{~m}$ $\mathrm{cu} ; 3 \mathrm{Cu}$ appears relatively short, terminating posterior to $1 \mathrm{rs}-\mathrm{m}$; $2 \mathrm{~A}$ fading to nebulous vein at midlength of cell $[2 \mathrm{Cu}]$. Hind wings poorly visible; apparent length near $0.64 \mathrm{~mm}$; only anterior veins partly visible; broad, open costal cell apparent near apex of $\mathrm{Sc}+\mathrm{R} ; \mathrm{R}$ appears to curve anteriorly and rapidly fade along anterior margin of wing; $2 \mathrm{Rs}$ and putative $1 \mathrm{rs}-\mathrm{m}$ both fade distally, and are removed from $1 \mathrm{R}$ by relatively long 1 Rs; faint curved vein within posterior portion of wing base assumed to represent $A$; marginal setae visible along posterior margin of wing are fine, elongate and relatively sparse, with greater density in apical positions. Legs with pervasive coat of short, stiff setae densely inclined upon most surfaces; pro- and mesocoxae with elongate setae inclined upon ventral surface; profemur with two rows of short, stiff setae suberect upon ventral surface, protibia bearing row of at least three stout spines approximately one-half of calcar's length on posterior surface; calcar gently curved and robust (as wide as probasitarsus), deeply inserted into protibial apex, extending only slightly beyond apex; fine setae inclined upon both sides of calcar, and matching longitudinal comb of erect spicules on basal half of probasitarsus; probasitarsus length slightly less than all subsequent tarsomeres combined, with approximately four irregularly distributed spines upon apical half of plantar surface; protarsomeres III and IV much shorter than others, one-half to two-thirds length of protarsomere V; all tarsi with serrate pretarsal claws and large arolium, with two apical spines on all tarsomeres (potentially absent 
on protarsomeres, but orientation obscures observation); meso- and metacoxae both approximately $1.5 \times$ length of procoxa, with broad bases and apical constriction; mesofemur with two rows of short, stiff setae inclined upon ventral surface; mesotibia with patch of fine, short spines along posterior surface near apex; two mesotibial spurs short and stout, slightly longer than apical width of mesotibia, and bearing minute setae along both margins; metafemur with significant midlength inflation, laterally compressed, with two rows of short, stiff setae suberect along ventral surface; metatibia with moderate apical expansion, bearing two apical spurs slightly longer than metatibial apical width, as well as comb-like row of six spicules each approximately twothirds of spurs' length; metatarsi not preserved. Metasoma with six apparent terga; terga appear to bear frills of elongate setae along posterior and lateral margins, terga more pilose within posterior of metasoma; parameres spatulate, each with four elongate setae erect on apex.

Female: Unknown.

Etymology. The specific epithet is the Latin diminutive noun in apposition, cellula (meaning, "small room") and refers to the very small size of cell [1Rs].

\section{Key to genera and species of Maimetshidae}

The following key is modified from that of Rasnitsyn and Brothers (2009).

1 Forewing with three submarginal cells, i.e. cells [1Rs] and [2Rs] both present, [1Rs] sometimes incompletely delimited (Fig. 7); flagellomere number 14-19 (unknown in Andyrossia Rasnitsyn and Jarzembowski).... .2

- $\quad$ Forewing with two submarginal cells, i.e. cells [1Rs] and [2Rs] not simultaneously present (Fig. 3); 14 flagellomeres.

2(1) Forewing $2 \mathrm{R} s+\mathrm{M}$ (second abscissa Rs+M, distal to $1 \mathrm{~m}-\mathrm{cu}$ ) shorter than $1 \mathrm{~m}$ cu to effectively absent (Figs $7,12 \mathrm{D})$................................................ 3 Forewing 2Rs+M (second abscissa Rs+M, distal to $1 \mathrm{~m}-\mathrm{cu}$ ) subequal to or longer than $1 \mathrm{~m}$-cu (Figs 9, 10, 14) ...............................................5

3(2) Forewing $1 \mathrm{~m}$-cu basad to second free abscissa of Rs such that $2 \mathrm{R} s+\mathrm{M}$ present (Fig. 7; Rasnitsyn et al. 1998: fig. 13) ...................................................4

- $\quad$ Forewing $1 \mathrm{~m}$-cu effectively confluent with second free abscissa of Rs such that $2 \mathrm{Rs}+\mathrm{M}$ absent (Figs 11, 12) (Neocomian, Lebanon)....

Abiromaimetsha najlae Perrichot, Azar, Nel \& Engel, gen. et sp. n.

4(3) Forewing cell [2Rs] not widened anteriorly; prestigma incrassate, about as long as 1Rs; 2m-cu present; pterostigma slightly widening apically (Figs. 5-7) (Albian, Spain)

.. Iberomaimetsha rasnitsyni Ortega-Blanco, Perrichot \& Engel, gen. et sp. n.

- $\quad$ Forewing cell [2Rs] widened anteriorly; prestigma linear, longer than 1Rs; 2m-cu absent; pterostigma linear (Rasnitsyn et al. 1998: fig. 13) (Barremian, England) Andyrossia joyceae (Rasnitsyn and Jarzembowski) 
5(2) Forewing cell [1Rs] not reduced, 1rs-m longer than 3Rs (abscissa of Rs distad 1rs-m; Fig. 10); pedicel, where known, not curved

- $\quad$ Forewing cell [1Rs] greatly reduced, 1rs-m much shorter than 3Rs (abscissa of Rs distad 1rs-m); pedicel arched (Figs 13, 14) (Campanian, Canada) ........ Abstemiam cellula McKellar \& Engel gen. et sp. n.

6(5) Notauli more or less parallel (Fig. 9) ………..............................................

- $\quad$ Notauli strongly diverging anteriorly (Rasnitsyn and Brothers 2009: fig. 7b) (Turonian, Botswana) .........Afromaimetsha robusta Rasnitsyn \& Brothers

7(6) Forewing Rs originating well before pterostigma, prestigma about as long as

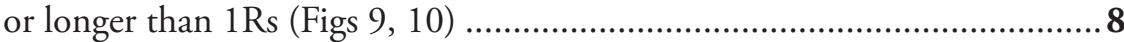

- $\quad$ Forewing Rs originating close to pterostigma, prestigma much shorter than 1Rs; prestigma incrassate, swollen apically and broader than basal abscissa Rs (Rasnitsyn and Brothers 2009: fig. 8b) (Turonian, Botswana).....

Maimetshorapia africana Rasnitsyn \& Brothers

8(7) Prestigma linear and similar to basal abscissa R (Rasnitsyn and Brothers 2009: figs 1, 2); 2m-cu absent (Genus Afrapia Rasnitsyn and Brothers) ................9

- $\quad$ Prestigma incrassate; $2 \mathrm{~m}$-cu present, nebulous (Figs 8, 9) (Albian, Spain) ..... Iberomaimetsha nibtmara Ortega-Blanco, Delclòs \& Engel, sp. n.

9(8) Pterostigma shorter than (about 0.8x) distance between base of Rs and 2r-rs (Rasnitsyn and Brothers 2009: fig. 1b) (Turonian, Botswana)

Afrapia globularis Rasnitsyn \& Brothers

- $\quad$ Pterostigma as long as or longer than distance between base of Rs and 2r-rs (Rasnitsyn and Brothers 2009: fig. 2b) (Turonian, Botswana)....

Afrapia variicornis Rasnitsyn \& Brothers

10(1) Forewing cell [1Rs] anteriorly petiolate; hind wing with free apex of $\mathrm{Cu}$; vertex without medial longitudinal line; compound eyes bulging; tarsal plantulae present in females (Figs 1-4) (latest Albian/earliest Cenomanian, France) Guyotemaimetsha enigmatica Perrichot et al.

- $\quad$ Forewing cell [1Rs] anteriorly sessile; hind wing without free apex of Cu; vertex with medial longitudinal line; compound eyes not bulging, almost following head contour; tarsal plantulae absent (Rasnitsyn 1975: fig. 87, pl. IV, figs. 14a, 14b) (Santonian, Siberia) Maimetsha arctica Rasnitsyn

\section{Discussion}

The new specimen from Canadian amber extends the temporal range of the family into the Campanian (from the Barremian to the Campanian), as the previous youngest exemplar was Maimetsha, from the Santonian amber of Taimyr (Siberia). Our new record also extends the palaeobiogeographic distribution of the family to encompass North America (from south Gondwana to north Laurentia), suggesting an origin during the Early Mesozoic, perhaps sometime in the mid-Jurassic. 
Certainly much remains to be undertaken on Maimetshidae, and research into the family is in its infancy. It will be exciting to develop eventually a broad data set meant to examine the interrelationships among the species (indeed, even addressing maimetshid monophyly!) as well along with their relatives among the Trigonalyidae and Megalyridae (along the lines of the study of Vilhelmsen et al. 2010a), and perhaps also among the Ceraphronoidea s.str. In addition, it is not entirely clear that those specimens known only from wing venation are definitively maimetshids, or alternatively, what other fragmentary taxa previously ascribed to Trigonalyidae or elsewhere might more accurately belong in or near Maimetshidae. Once a thorough cladistic analysis has been undertaken for maimetshids, preferably after a greater wealth of diversity and material is discovered and more species analyzed using modern tools such as synchrotron imaging, then the generic classification of the family should be re-evaluated as it presently appears somewhat finely divided.

For now, what started as a singular species discovered and presciently interpreted by Alex Rasnitsyn 36 years ago (Rasnitsyn 1975), has grown rapidly in diversity within the last six years. We can only hope that this trend will continue in the years to come.

\section{Acknowledgements}

The senior author is particularly grateful to the late Eugène Arnaud who was fascinated by paleontology and collected a lot of amber from the French deposit of Cadeuil, all of which he gave generously to VP for study. Arnaud's material contained the best preserved specimen of the French species. Simon Fortis, Malvina Lak, and Carmen Soriano are gratefully acknowledged for contributing the synchrotron imaging of three specimens; Didier Néraudeau for his active participation in collecting the French material; the Marchand family for facilitating access to their property; and Rafael Lopez del Valle for the delicate preparation of the Spanish specimens. Partial support was provided by U.S. National Science Foundation grants EF-0341724 and DEB-0542909 (both to MSE), by the Spanish Ministry of Science and Innovation through project CGL2008-00550/BTE (to XD and JOB), by French-Spanish project PICASSO from EGIDE and Spanish Ministry of Science and Technology (09045SE to VP and XD), by French National Research Agency grant BLAN07-1-184190 (project AMBRACE to D Néraudeau, University Rennes 1), by the ESRF through attribution of inhouse beamtime on the beamline ID 19, by the Lebanese University through project "Fossil Insects in Lebanon and their Outcrops: Biodiversity, Origin, Structure, Evolution, and Geology" (to DA), by NSERC and Alberta Ingenuity Fund support (to RCM), and by NSERC Discovery Grants (to BDE Chatterton and AP Wolfe, University of Alberta). Lastly, we thank two anonymous reviewers for their helpful input with the manuscript. This is a contribution of the Division of Entomology, University of Kansas Natural History Museum. 


\section{References}

Azar D, Gèze R, Acra F (2010) Lebanese amber. In: Penney D (Ed) Biodiversity of Fossils in Amber from the Major World Deposits. Siri Scientific Press, Manchester, 271-298.

Batten DJ, Colin JP, Néraudeau D (2010) Megaspores from mid Cretaceous deposits in western France and their biostratigraphic and palaeoenvironmental significance. Review of Palaeobotany and Palynology 161: 151-167. doi: 10.1016/j.revpalbo.2010.03.012

Carmean D, Kimsey L (1998) Phylogenetic revision of the parasitoid wasp family Trigonalidae (Hymenoptera). Systematic Entomology 23(1): 35-76. doi: 10.1046/j.13653113.1998.00042.x

Cresson ET (1887) Synopsis of the families and genera of the Hymenoptera of America, north of Mexico, together with a catalogue of the described species, and bibliography. Transactions of the American Entomological Society, Supplement 1887: viii+1-350+[1: errata]

Corral JC, López del Valle R, Alonso J (1999) El ámbar cretácico de Álava (Cuenca VascoCantábrica, norte de España): Su colecta y preparación. Estudios del Museo de Ciencias Naturales de Álava 14(special publication 2): 7-21.

Davis RB, Baldauf SL, Mayhew PJ (2010) The origins of species richness in the Hymenoptera: Insights from a family-level supertree. BMC Evolutionary Biology 10: 109. doi: 10.1186/1471-2148-10-109

Dejax J, Masure E (2005) Analyse palynologique de l'argile lignitifère à ambre de l'Albien terminal d'Archingeay (Charente-Maritime, France). Comptes Rendus Palevol 4(1/2): 53-65. doi: 10.1016/j.crpv.2004.12.002

Engel MS, Grimaldi DA (2009) Diversity and phylogeny of the Mesozoic wasp family Stigmaphronidae (Hymenoptera: Ceraphronoidea). Denisia 26: 53-68.

Engel MS, Grimaldi DA, Ortega-Blanco J (2011) Serphitid wasps in Cretaceous amber from New Jersey (Hymenoptera: Serphitidae). Insect Systematics and Evolution 42(2): 197-204. doi: $10.1163 / 187631211$ X 560892

Gibson GAP, Read J, Huber JT (2007) Diversity, classification and higher relationships of Mymarommatoidea (Hymenoptera). Journal of Hymenoptera Research 16(1): 51-146.

Goulet H, Huber JT (1993) Hymenoptera of the World: An Identification Guide to Families. Agriculture Canada, Ottawa, vii+668 pp.

Heraty J, Ronquist F, Carpenter JM, Hawks D, Schulmeister S, Dowling AP, Murray D, Munro J, Wheeler WC, Schiff N, Sharkey M (2011) Evolution of the hymenopteran megaradiation. Molecular Phylogenetics and Evolution 60(1): 73-88. doi: 10.1016/j.ympev.2011.04.003

ICZN (1999) International Code of Zoological Nomenclature. International Trust for Zoological Nomenclature, London, 306 pp.

Kozlov MA, Rasnitsyn AP (1979) On the limits of the family Serphitidae (Hymenoptera, Proctotrupoidea). Entomologicheskoe Obozrenie 58(2): 402-416. [In Russian]

Lak M, Néraudeau D, Nel A, Cloetens P, Perrichot V, Tafforeau P (2008) Phase contrast X-ray synchrotron imaging: Opening access to fossil inclusions in opaque amber. Microscopy and Microanalysis 14(3): 251-259. doi: 10.1017/S1431927608080264 
Linnaeus C (1758) Systema Naturae per regna tria natura, secundum classes, ordines, genera, species, cum characteribus, differentiis synonymis, locis $\left[10^{\text {th }}\right.$ Edition, revised]. Laurentii Salvii, Holmiae, Stockholm, 824 pp.

McKellar RC, Engel MS (2011) The serphitid wasps (Hymenoptera: Proctotrupomorpha: Serphitoidea) of Canadian Cretaceous amber. Systematic Entomology 36(1): 192-208. doi: 10.1111/j.1365-3113.2010.00559.x

McKellar RC, Engel MS (in press) New Stigmaphronidae and Megaspilidae (Hymenoptera: Ceraphronoidea) from Canadian Cretaceous amber. Cretaceous Research. doi: 10.1016/j. cretres.2011.05.008

McKellar RC, Wolfe AP (2010) Canadian amber. In: Penney D (Ed) Biodiversity of Fossils in Amber from the Major World Deposits. Siri Scientific Press, Manchester, 149-166.

Néraudeau D, Perrichot V, Dejax J, Masure E, Nel A, Philippe M, Moreau P, Guillocheau F, Guyot T (2002) Un nouveau gisement à ambre insectifère et à végétaux (Albien terminal probable): Archingeay (Charente-Maritime, France). Geobios 35(2): 233-240. doi: 10.1016/S0016-6995(02)00024-4

Oeser R (1962) Der reduzierte Ovipositor von Pseudogonalos hahni (Spin.) nebst Bemerkungen über die systematische Stellung der Trigonalidae. Wandersammlung Deutscher Entomologen Bericht 9: 153-157.

Ortega-Blanco J, Rasnitsyn AP, Delclòs X (2010) A new family of ceraphronoid wasps from Early Cretaceous Álava amber, Spain. Acta Palaeontologica Polonica 55(2): 265-276. doi: 10.4202/app.2009.0014

Ortega-Blanco J, Peñalver E, Delclòs X, Engel MS (2011a) False fairy wasps in Early Cretaceous amber from Spain (Hymenoptera: Mymarommatoidea). Palaeontology 54(3): 511523. doi: 10.1111/j.1475-4983.2011.01049.x

Ortega-Blanco J, Delclòs X, Peñalver E, Engel MS (2011b) Serphitid wasps in Early Cretaceous amber from Spain (Hymenoptera: Serphitidae). Cretaceous Research 32(2): 143-154. doi: 10.1016/j.cretres.2010.11.004

Ortega-Blanco J, Delclòs X, Engel MS (In press) Diverse stigmaphronid wasps in Early Cretaceous amber from Spain (Hymenoptera: Ceraphronoidea: Stigmaphronidae). Cretaceous Research doi: 10.1016/j.cretres.2011.05.004

Peñalver E, Delclòs X (2010) Spanish amber. In: Penney D (Ed) Biodiversity of Fossils in Amber from the Major World Deposits. Siri Scientific Press, Manchester, 236-269.

Perreau M, Tafforeau P (2011) Virtual dissection using phase-contrast X-ray synchrotron microtomography: Reducing the gap between fossils and extant species. Systematic Entomology 36(3): 573-580. doi: 10.1111/j.1365-3113.2011.00573.x

Perrichot V (2009) Long-tailed wasps (Hymenoptera: Megalyridae) from Cretaceous and Paleogene European amber. Paleontological Contributions 1: 1-35.

Perrichot V, Nel A, Néraudeau D (2004a) A new, enigmatic, evaniomorphan wasp in the Albian amber of France (Insecta: Hymenoptera). Journal of Systematic Palaeontology 2(2): 159-162. doi: 10.1017/S1477201904001245 
Perrichot V, Nel A, Néraudeau D (2004b) Two new wedge-shaped beetles in Albo-Cenomanian ambers of France (Coleoptera: Ripiphoridae: Ripiphorinae). European Journal of Entomology 101(4): 583-589.

Perrichot V, Néraudeau D, Tafforeau P (2010) Charentese amber. In: Penney D (Ed) Biodiversity of Fossils in Amber from the Major World Deposits. Siri Scientific Press, Manchester, 192-207.

Rasnitsyn AP (1975) Hymenoptera Apocrita of the Mesozoic. Trudy Paleontologicheskogo Instituta, Akademiia Nauk SSSR [Transactions of the Paleontological Institute, Academy of Sciences USSR] 147: 1-132. [In Russian]

Rasnitsyn AP (1977) New Hymenoptera from the Jurassic and Cretaceous of Asia. Paleontologicheskiy Zhurnal 3: 98-108. [In Russian: English translation in Paleontological Journal 1978, 11(3): 349-357]

Rasnitsyn AP (1988) An outline of evolution of the hymenopterous insects (order Vespida). Oriental Insects 22: 115-145.

Rasnitsyn AP (1990) Hymenopterans: Vespida. Trudy Paleontologicheskogo Instituta Akademii Nauk SSSR 239: 177-205. [In Russian]

Rasnitsyn AP (1991) Early Cretaceous members of evaniomorphous hymenopterans of the families Stigmaphronidae and Cretevaniidae and subfamily Kotujellitinae (Gasteruptiidae). Paleontologicheskiy Zhurnal 4: 128-132. [In Russian]

Rasnitsyn AP (2002) Superorder Vespidea Laicharting, 1781. Order Hymenoptera Linné, 1758 (= Vespida Laicharting, 1781). In: Rasnitsyn AP, Quicke DLJ (Eds) History of Insects. Kluwer Academic Publishers, Dordrecht, 242-254. doi: 10.1007/0-306-47577-4

Rasnitsyn AP, Brothers DJ (2009) New genera and species of Maimetshidae (Hymenoptera: Stephanoidea s.l.) from the Turonian of Botswana, with comments on the status of the family. African Invertebrates 50(1): 191-204.

Rasnitsyn AP, Jarzembowski EA (2000) A replacement name for the parasitoid wasp Arossia Rasnitsyn et Jarzembowski non Newman. Cretaceous Research 21(4): 587. doi: 10.1006/ cres. 2000.0213

Rasnitsyn AP, Zhang H (2010) Early evolution of Apocrita (Insecta, Hymenoptera) as indicated by new findings in the Middle Jurassic of Daohugou, northeast China. Acta Geologica Sinica 84(4): 834-873. doi: 10.1111/j.1755-6724.2010.00254.x

Rasnitsyn AP, Jarzembowski EA, Ross AJ (1998) Wasps (Insecta: Vespida = Hymenoptera) from the Purbeck and Wealden (Lower Cretaceous) of southern England and their biostratigraphical and palaeoenvironmental significance. Cretaceous Research 19(3/4): 329-391. doi: $10.1006 /$ cres.2000.0213

Ronquist F, Rasnitsyn AP, Roy A, Eriksson K, Lindgren M (1999) Phylogeny of the Hymenoptera: A cladistic reanalysis of Rasnitsyn's (1988) data. Zoologica Scripta 28(1/2): 13-50. doi: 10.1046/j.1463-6409.1999.00023.x

Sharkey M (2007) Phylogeny and classification of Hymenoptera. Zootaxa 1668: 521-548.

Sharkey MJ, Roy A (2002) Phylogeny of the Hymenoptera: A renanalysis of the Ronquist et al (1999) reanalysis, emphasizing wing venation and apocritan relationships. Zoologica Scripta 31(1): 57-66. doi: 10.1046/j.0300-3256.2001.00081.x 
Shaw SR (1988) Carminator, a new genus of Megalyridae (Hymenoptera) from the Oriental and Australian regions, with a commentary on the definition of the family. Systematic Entomology 13(1): 101-113. doi: 10.1111/j.1365-3113.1988.tb00233.x

Shaw SR (1990) Phylogeny and biogeography of the parasitoid wasp family Megalyridae (Hymenoptera). Journal of Biogeography 17(6): 569-581. doi: 10.2307/2845141

Soriano C, Archer M, Azar D, Creaser P, Delclòs X, Godthelp H, Hand S, Jones A, Nel A, Néraudeau D, Ortega-Blanco J, Pérez-de la Fuente R, Perrichot V, Saupe EE, Solórzano Kraemer MM, Tafforeau P (2010) Synchrotron X-ray imaging of inclusions in amber. Comptes Rendus Palevol 9(6/7): 361-368. doi: 10.1016/j.crpv.2010.07.014

Tafforeau P, Boistel R, Boller E, Bravin A, Brunet M, Chaimanee Y, Cloetens P, Feist M, Hoszowska J, Jaeger JJ, Kay RF, Lazzari V, Marivaux L, Nel A, Nemoz C, Thibault X, Vignaud P, Zabler S (2006) Applications of X-ray synchrotron microtomography for non-destructive 3D studies of paleontological specimens. Applied Physics A: Materials Science and Processing 83(2):195-202. doi: 10.1007/s00339-006-3507-2

Vilhelmsen L, Perrichot V, Shaw SR (2010a) Past and present diversity and distribution in the parasitic wasp family Megalyridae (Insecta: Hymenoptera). Systematic Entomology 35(4): 658-677. doi: 10.1111/j.1365-3113.2010.00537.x

Vilhelmsen L, Mikó I, Krogmann L (2010b) Beyond the wasp-waist: Structural diversity and phylogenetic significance of the mesosoma in apocritan wasps (Insecta: Hymenoptera). Zoological Journal of the Linnean Society 159(1): 22-194. doi: 10.1111/j.10963642.2009.00576.x 